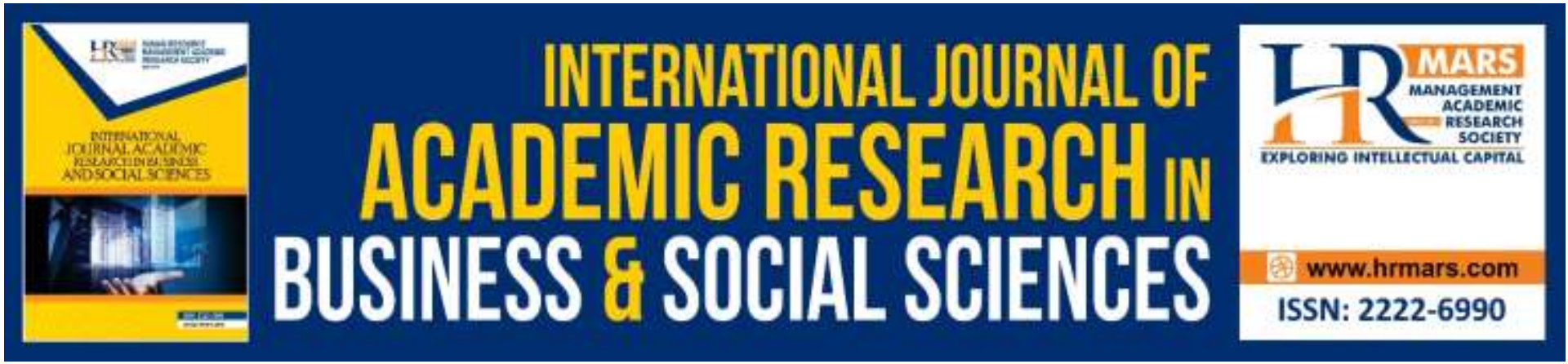

\title{
Household's Non-Leisure Time Allocation for Children in Indonesia
}

Dayang Haszelinna Abang Ali, Rosita Hamdan, Audrey Liwan, Josephine Yau Tan Hwang

To Link this Article: http://dx.doi.org/10.6007/IJARBSS/v9-i9/6339

DOI: $10.6007 /$ IJARBSS/v9-i9/6339

Received: 29 July 2019, Revised: 30 August 2019, Accepted: 02 September 2019

Published Online: 29 September 2019

In-Text Citation: (Ali, Hamdan, Liwan, \& Hwang, 2019)

To Cite this Article: Ali, D. H. A., Hamdan, R., Liwan, A., \& Hwang, J. Y. T. (2019). Household's Non-Leisure Time Allocation for Children in Indonesia. International Journal of Academic Research in Business and Social Sciences, 9(9), 624-653.

\section{Copyright: (C) 2019 The Author(s)}

Published by Human Resource Management Academic Research Society (www.hrmars.com)

This article is published under the Creative Commons Attribution (CC BY 4.0) license. Anyone may reproduce, distribute, translate and create derivative works of this article (for both commercial and non-commercial purposes), subject to full attribution to the original publication and authors. The full terms of this license may be seen at: http://creativecommons.org/licences/by/4.0/legalcode

\section{Vol. 9, No. 9, 2019, Pg. 624 - 653}

Full Terms \& Conditions of access and use can be found at http://hrmars.com/index.php/pages/detail/publication-ethics 


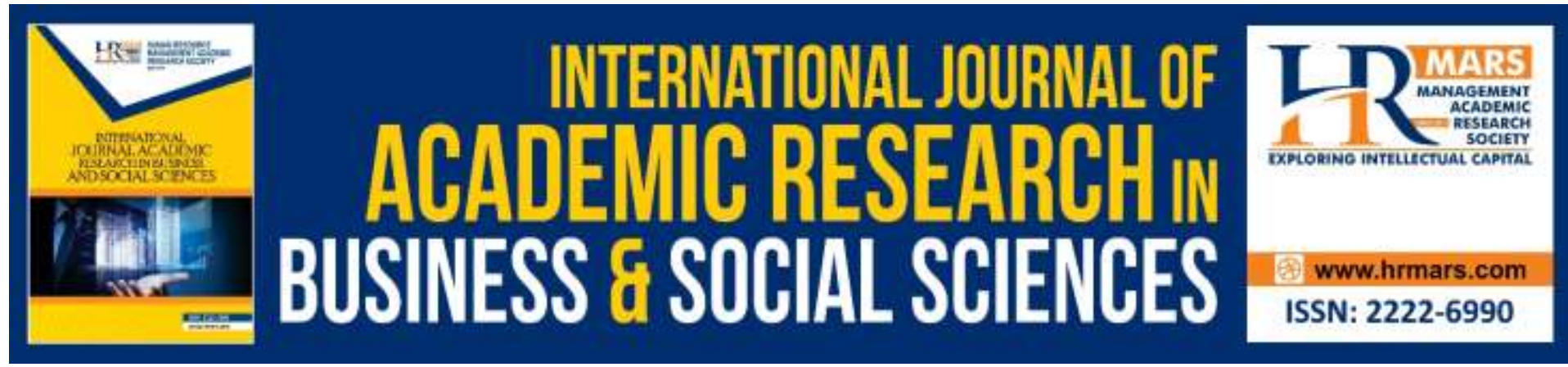

\title{
Household's Non-Leisure Time Allocation for Children in Indonesia
}

\author{
Dayang Haszelinna Abang Ali ${ }^{1}$, Rosita Hamdan², Audrey \\ Liwan², Josephine Yau Tan Hwang ${ }^{2}$ \\ ${ }^{1}$ Center for Policy Research and International Studies, Universiti Sains Malaysia, ${ }^{2}$ Faculty of \\ Economics and Business, Universiti Malaysia Sarawak \\ Email*: dyghaszelinna@usm.my
}

\begin{abstract}
This study is an attempt to provide an understanding on why an Indonesian child is doing one activity and not another one. Households are assumed to maximize their utility by making decisions about time allocation for their children among four different activities: school only, work and school, work only, and neither work nor school. Using data from The National Socioeconomic Survey (SUSENAS) in Indonesia, the impact of child, household and community characteristics were examined along with basic services and infrastructures on children outcomes. The results show that having basic services significantly affects the probability of combining work and school, work only and neither work nor schooling. However, no significant impact is observed on the probability of children attending school in the year of the survey.
\end{abstract}

Keywords: Non-Leisure Time Allocation, Child Labor, Indonesia, Multinomial Logit

\section{Introduction}

In Indonesia, children stereotypically initiate working around age five. Recent labor force survey revealed that labor force participation rate of children ages 10-14 was about $3.7 \%$ in 2016 (UNESCO Institute of Statistics, 2018). In addition, approximately, $82 \%$ of the total numbers of children (58.8 million) attend school. Hence, for children who are involved in economic activities while simultaneously attending school, the extent of how labor supply affects the quantity of time that is allocated to develop skills comes into question. Moreover, $6 \%$ of the total numbers of children are in the category of neither work nor schooling. There are several reasons which hinder children from going to school. For children, their time allocation is decided by parents, who directly affect the child's current utility. It has been argued that the households wherein children live determine the ways how children spend their time. According to Bonsang and Faye (2005), households allocate time for different activities among their household members through an internal mechanism. In addition, they also allocate household resources for consumption, saving and investment including human capital formation between themselves.

Thus, children's activities heavily rely on factors that may affect household's constraints, opportunities and incentives. The decision of sending children to school or not 
depends on the extent to which households need their labor to reach some level of welfare. On the other hand, if a child is engaged in work, he or she receives less education which results in lower earnings in the future. A child can go to school full time or work full time or combine work and school or do neither work nor study. Since the majority of children who were sent to work are from poor families, the fact that education serves as an engine for both the social and economic development of most societies was ignored, especially in rural areas. However, concurrent working and studying has a negative impact on the transition to secondary school (Ridao-Cano, 2001). Consequently, children tend to drop out of school, which leads them to participate in full-time work, or to participate neither in school nor work.

This study considers four alternatives of the non-leisure time allocation of children. These activities include school only, work only, concurrent working and studying and do neither work nor school. By considering 'idleness' or neither work nor schooling, explicitly as one of the activities along with schooling, and working seems to be significant from a policy perspective (Ranjan, 2004). Furthermore, children may be "idle" because there are no work opportunities. All at once, parents' perceived low returns from schooling prohibit them to send their children to school. Therefore, neither work nor school category is necessary to be included in analyzing the time allocation of children in Indonesia. This is particularly true in rural areas where access to school may be difficult, in terms of the distance to school. However, as mentioned earlier, the household decisions on their child's time allocation is mainly depending on the household's perception of the highest relative returns from one of the activities. According to Ranjan, the policy of increasing child schooling either by improving the school facilities or providing subsidies and increase the budget on education, should be managed to pull out the 'idle' children to enrol in school. Government expenditure on Indonesia's education is comparably lower than of its neighbouring countries, such as Malaysia and Thailand. The proportion of allocated budget compared with Gross Domestic Product (GDP) was only $1.4 \%$. This proportion is the lowest compared to Malaysia $(4.9 \%$ of GDP) and Thailand (4.8\% of GDP), and it is even lower than China where they allocated $2.3 \%$ of its GDP for education despite China having a much higher population compared to Indonesia (National Coordination Forum of Education for All, 2003).

Children's activities in Indonesia were postulated depending on the level of child characteristics, household characteristics, community characteristics and the availability of basic services such as access to drinkable water, sanitation, electricity and number of schools. The four types of mutually exclusive activities were distinguished in which children are engaged, which are attending school only, work only, combine both schooling and working and neither work nor schooling. The primary objective of this research is to provide a better understanding of the determinants of non-leisure time allocation of children in Indonesia. This includes a leisure time instead of schooling and working. The role of access to basic services and facilities can affect the value of children's time and household decisions on how their child's time is allocated. Therefore, this study also investigates the link between child activity and basic services (water, sanitation and electricity access) and facilities (number of schools, student-teacher ratio, telephone and computer) in Indonesia.

\section{Literature Review}

According to Edmonds (2003), after a period of child labor, children may not return to school. Returning to not working may be relatively low because schooling may be unavailable or expensive, in terms of costs and travel time. A very low quality school has a strong relationship with low school attendance and consequently, a poor household's information 
on the return to their child's education may induce them to reduce education and keep their children at work, or both.

In Peru, working allows indigenous children to continue enrolling in school (Patrinos and Psacharopoulos, 1997). They believe that children can attend school and work, with apparently no negative effect on their school progress. In the case of children in India, Kambhampati and Rajan (2008) found that an observation on child labor over two years across the major states of India revealed that the pattern of schooling and child work has been changed. The participation rates among children across all activity ${ }^{1}$ types, including schooling, had increased. However, a study by Ridao-Cano (2001) concluded that working though in school has a negative impact on the transition to secondary school. In particular, those children with a higher propensity to work are associated with lower school outcomes.

Evidence from Pakistan and Nicaragua, as shown by Rosati and Rossi (2002), revealed that fewer working hours led to increases in school attendance. They argued that the changes in the probability of attending children to school will determine the effects of the variables on the hours worked (see also Triningsih and Ichihashi, 2010). The marginal effect is different among children who are attending school and/or work and this will have different impacts on policy, depending on if the children like to work or not. Besides, if a child starts to work one year earlier and does not go to school, the loss in his adult earnings is equivalent to having lost more than one extra year of schooling. In urban Brazil, Duryea and Arends-Kuenning (2003) demonstrated that employment rates of children are high, as local labor market opportunities improve; it means that it is more favourable for children to leave school and participate in the labor market. A study of Akabayashi and Psacharopoulos (1999) of Tanzanian children finds that there is a trade-off between hours of work and study. However, there is no evidence of variables that increase both working and studying significantly at the same time. Hours of work are significantly affected by community variables such as electricity supply and distance to water, however, less effect are found on the hours of study. In addition, the development of children's reading and mathematical skills are negatively correlated to the hours of work. This shows that working and human capital investment is not mutually exclusive.

Using crop and rainfall shocks as instrumental variables for child labor, Beegle et al. (2008) examined the consequences of child labor on education, employment choices and marital status over a 10 -year horizon among children in Tanzania. Their findings showed a negative and significant effect of child labor on school years and on the probability of completing primary school 10 to 13 years later. In particular, one standard deviation increase in child labor hours is associated with a reduction in terms of half a year of schooling, plus an 8.8 percentage point reduction in the chance of completing primary school. Therefore, individuals who worked when they were young are significantly more likely to be farming in adulthood In Paraguay, Patrinos and Psacharopolous (1995) analyse the factors that contributes to the increase in child labor which also reduced school attendance and increase the chance of grade repetition. By controlling the children's age, gender and language usually spoken at home, the empirical result shows that child work is a significant predictor of agegrade distortion. Heady (2003) analyses the effect of children's work on learning achievement by using measures of reading and mathematics ability. He finds a negative relationship between child labor and learning achievement. In addition, they also find that work had relatively little impact on school attendance. Evidence from Bangladesh also reveals a

\footnotetext{
${ }^{1}$ Which is commonly in the agriculture sector.
} 
negative relationship between work and child's school enrolment (Khanam and Ross, 2005). In particular, working children are 88 percentage points less likely to be enrolled in school relative to non-working children. A gender-divide estimate reveals that working girls and boys are $75 \%$ and $88 \%$ less likely to be enrolled in school. Another study of working children in Bangladesh by Islam et al. (2009) finds that the school attendance of working children are strongly depended on the hours worked. Their logistic regression results show the highly significant and negative influence of hours worked on school attendance of working children. Children who work 5-9 hours per day are $96 \%$ less likely to attend school and those who work more than 10 hours per day are about $99 \%$ less likely to attend school than children who work 5 hours per day. This condition is due to the fact that children who are spending more time at work have a very little time to go to school.

\section{Theoretical Framework}

Following Burki and Fasih (1998), households are assumed to be rational decisionmaking units that make choices between leisure time and consumption of goods to maximize their utility subject to time and budget constraints. Children are considered not to make their own decisions independently. In other words, children are under the control of their parents. Therefore, considering the time allocation of different members of the household and the assumption that the household maximizes the following utility function:

$$
U=U\left(L_{h}, L_{w}, L_{c}, Y\right)
$$

where $L_{h}$ is leisure hours for the husband, $L_{w}$ is leisure hours for the wife, $L_{c}$ is leisure hours for children in the household, and $Y$ is the Hicksian composite good representing the consumption of all goods other than leisure ${ }^{2}$. The budget constraint facing the household is given by : $^{3}$

$$
W_{h} L_{h}+W_{w} L_{w}+W_{c} L_{c}+P_{y} Y=M \equiv I+W_{h} \delta_{h}+W_{w} \delta_{w}+W_{c}
$$

where $W_{h}, W_{w}$ and $W_{c}$ are the wage rates of the husband, wife, and children; $P_{y}$ represents the price of the composite good, $I$ is non-labor income, $M$ is full income, and $\delta$ is the total number of hours available for work, where;

$L+\delta=T$

where $T$ is the total time. Maximizing the household utility function (1) subject to the budget constraint (2) produces the demand functions for the leisure of the husband, wife and children, and for consumption of the composite good, which is:

$$
\begin{aligned}
& L_{i}=F_{i}\left(W_{h}, W_{w}, W_{c}, P_{y} ; M\right) \\
& Y=F_{y}\left(W_{h}, W_{w}, W_{c}, P_{y} ; M\right)
\end{aligned} \quad i=h, w, c
$$

Substituting these optimized demand functions (3) into the utility function (1) gives the indirect utility function for each household, which is maximized by given prices and incomes. As stated by McFadden (1973), there are errors in the maximization process, due to imperfect information, knowledge, and perception of the households; this creates a random function of household utility. Following Maddala (1983), by presume that households face ' $m$ ' choices for

${ }^{2} Y$ is a composite Hicksian commodity under the assumption that the relative prices of different commodities are the same for all individuals throughout the analysis (see Wales and Woodland, 1977).

${ }^{3}$ We assumed that the time spent on household activities does not include in the leisure time. 
children's time allocation and a latent variable, $V_{k}^{*}$ is defined, indicating the level of indirect utility attached with the $k^{\text {th }}$ choice, the variable $V_{k}^{*}$ is shown by:

$V_{k}=1$ if $V_{k}=\operatorname{Max}\left(V_{1}^{*}, V_{2}^{*}, \ldots \ldots, V_{m}^{*}\right)$

$V_{k}=0$ otherwise

The variable $V_{k}$ is decomposed into a non-stochastic component, $V_{k}\left(X_{k}\right)$ and a stochastic component, $\varepsilon_{k}$, (Burki and Fasih, 1998, p.901), which is written as:

$$
V_{k}=V_{k}\left(X_{k}\right)+\varepsilon_{k} \quad k=1,2, \ldots \ldots, m
$$

where $X_{k}$ is the vector of attributes of the $k^{\text {th }}$ choice and the errors in perception and optimization are denoted by $\varepsilon_{k}$. A typical household is assumed to choose among four mutually exclusive alternatives: only school, work and school, only work, and neither work nor school, which are categorized as 1, 2, 3, and 4, respectively. A household maximizes its utility function subject to the budget and time constraints that were modified to reflect the respective costs and returns imposed by each of the choices, and this result in four indirect utility functions. The household will choose the alternative that maximizes the households' indirect utility by comparing the levels of indirect utility. Thus, the probability that child $i$ participate in the $k^{\text {th }}$ activity is the probability that the indirect utility from the $k^{\text {th }}$ choice is greater than what derived from other choices (Burki and Fasih, 1998, p.901), which is given by:

$P_{i k}=P_{r}\left(V_{i k}>V_{i j}\right) \quad \forall j \neq k, j=1,2,3,4$

This denotes that the probability of child $i$ participating in choice $k$ is the probability that the difference between the stochastic components is greater than the difference between the non-stochastic components, or:

$$
P_{i k}=P_{r}\left(\varepsilon_{i k}-\varepsilon_{i j}>V_{i j}-V_{i k}\right) \quad \forall j \neq k, j=1,2,3,4
$$

\section{Data Description}

The data set used in this study comes from a survey of The National Socioeconomic Survey (SUSENAS) conducted in 2007 by the Statistics Indonesia. The SUSENAS records labor force participation and educational information for all household members with the age of 10 years and above which contains questions on labor market participation and educational attainment addressed at adults and children in the household, socioeconomic conditions, employment, working conditions, school participation and highest educational level achievement. Children who are reported doing housework are excluded from the sample. Moreover, 921 households in the survey also excluded from the sample due to missing data points, which is related to spouse's characteristics. Final sample of 155,327 children in the age cohort of 10-17 years were collected. In addition, the data from published report provided by Statistics Indonesia which include the percentage of households that have basic services and facilities in each province were also utilized in this study.

\section{Dependent Variables}

To create dependent variables, the information from the survey were utilized as below:

a) School participation (1. Attending school, 2. Never attended/Not yet, 3. Not in school anymore) 
b) Of these activities (schooling, working, housework, others), which one consumed most of your time in the last one week?

Children's activities in Indonesia were postulated based on the household and community characteristics. Those children who are consuming most of their time doing housework in the previous week are excluded from the sample. In addition, 'others' category in the questionnaire were presumed as in neither work nor schooling. Thus, children in 'others' category is included in sample as well. These are distinguished by the four types of mutually exclusive activities in which children are engaged using the information given in SUSENAS 2007, as follows:

i) Children who are going to school and not working.

ii) Children who are working and going to school.

iii) Children who are working and not going to school.

iv) Children who are not working and not going to school.

These four categories are used as a dependent variable in the analysis. The major decision making regarding these four choices are at the household level. In other words, the decision makers are the parents or caretakers of the children. They select the choices that maximise their utility subject to their budget and time constraints.

\section{Explanatory Variables}

To capture child characteristics, the variables gender, age and relationship to the head of the household were used. Gender of the children is included in the model in dummy form with boy as the base category. The value of the child time depends on the child's age. The returns to schooling for younger children may be sufficiently high since they spend most of their time in school. On the other hand, older children may work since they are able to earn higher wages in the labor market. Therefore, apart from continuous variable of age, the age is divided to three groups of dummy, such as 10-12 years, 13-14 years (reference category) and 15-17 years to investigate the effects. Biological child is a dummy variable equal to 1 if the child is a biological child of the household head.

Household head characteristics include the gender, age, education and employment of the head of the household. These variables have been included in thes analysis because it is expected that the head has an important role in the decision making process on time allocation of the child. In addition, spouse characteristics such as education and employment of the spouse are included to examine the impact on child's activity. The educational level of head of the household and the spouse was entered as dummy variables for each of categories (no schooling, completed primary, junior secondary, senior secondary and tertiary education). No schooling is used as the base category. For the employment status of the household head and spouse, five employment categories were identified using separate dummies such as self-employed (reference category), employer, employee, casual worker, unpaid worker and others. The gender of the household head was included as a dummy which takes value of 1 if the gender of the household head is female.

Household living standards are a key aspect in determining how much a child works. In particular, poor households have higher marginal utilities of current consumption which the value of an additional unit of child work is higher than a rich household. As a proxy of living standard, household income which captures the non-child labor earnings of the 
household were included. In other words, household income is obtained by subtracting the child's income from the reported household income (sum of income from all other household members). A similar approach is implemented by Jeong (2005). According to Jeong, there could be a positive effect flowing the reverse direction if household income does not subtract the child's contribution. Due to this potential simultaneity bias, child's income is subtracted from household income.

The rank of a sibling affects a decision of household in choosing which children are sent to work or to school. As found by Khanam and Rahman (2005) in Bangladesh, a first-born child increases the probability of working or at least combining school with work and the laterborn children are more likely to be in school than their earlier-born siblings. A larger household size decreases income per household which reduces children's educational participation and parental investment in schooling (Grootaert and Patrinos, 2002). These will increase the likelihood that children will need to generate income to make ends meet. However, according to Grootaert and Patrinos (2002), each child does not have the same probability to be sent to school or to work; that likelihood depends on child's age and gender (see also Patrinos and Psacharapolous, 1997). Therefore, the number of children based on the groups of age of 0-5 years, 6-9 years, 10-14 years and 15-17 years were counted in the analysis. The variable of the number of adults in the household is to examine the effects on child's activity. Moreover, a dummy of region also included, where rural takes a value of 1 if the household resides in rural areas and 0 otherwise.

Variables have been added to investigate the effects of having facilities on making the decisions. All these variables are drawn from published report made by Statistics Indonesia in 2007. According to Bonsang and Faye (2005), these basic services and facilities can be used as an instrument for reducing child labor and increasing school attendance. The variables are the percentage of households that own their dwellings, the percentage of households that have improved drinking water, the percentage of households that have improved sanitation, and the percentage of households that have a source of electricity. Most of these variables specify that working children are those who are in households with poor living conditions, while those attending school have better living standards (Bonsang and Faye, 2005). In addition, Rickey (2009) stated that communities with better and more established infrastructures and facilities would have higher school attendance since the costs would be less. Moreover, the availability of these services may affect the value of children's time. A lack of access to water raise the value of children's time in non-schooling activities such as working (fetch water for household use) or neither work nor schooling (cannot afford the cost of schooling). As found by Guarcello et al (2004), the percentage of children who work only and neither work nor schooling is higher and the rate of school only is lower among children from households without water or electricity access. Since children activities in the sample are not mutually exclusive, it is valuable to examine a correlation between basic services and the activities of children.

In terms of schooling, the number of schools is used to examine whether a high number of schools provided in each province attracts children to attend school. In addition, schools that provide sufficient facilities, including teacher availability, encourage students to attend school. Classes with too many students affect most of the low-attaining students. This is due to too much attention given by the teacher to all students instead of individual attention. Hence, the student-teacher ratio is included to investigate the effects on the household decision. This information also gathered from published report by Ministry of National Education in Indonesia which is available for each province in Indonesia. 
Furthermore, households that own a telephone and computer are included in the model, to observe the effects of having these two facilities on the child's status. These variables are found in the questionnaire, which is entered as a dummy variable that takes a value of 1 if the household have telephone and computer and 0 otherwise. To measure the size of each region's economy, gross regional domestic product (GRDP) is used in terms of GRDP per capita, which used an indicator of standard of living or a regional's average wealth. This is positively related to school attendance and negatively related to child labor. This GRDP per capita is also obtained from Statistics Indonesia.

To avoid multicollinearity, the provinces are grouped into 7 main islands: Sumatera (NAD, North Sumatera, West Sumatera, Riau, Jambi, South Sumatera, Bengkulu, Lampung, Bangka-Belitung, and the Riau Islands), Java (DKI Jakarta, West Java, Central Java, DIY, East Java, and Banten), Lesser Sunda Islands (Bali, West Nusa Tenggara and East Nusa Tenggara), Kalimantan (West Kalimantan, Central Kalimantan, South Kalimantan and East Kalimantan), Sulawesi (North Sulawesi, Central Sulawesi, South Sulawesi and Southeast Sulawesi), Maluku (North Maluku and Maluku), and New Guinea (West Papua and Papua). In other words, this is due to a small observation of children in some provinces in each activity. Thus, the provinces are grouped into 7 major islands in Indonesia. Hence, 7 dummy variables are created such as Sumatera, Java, Lesser Sunda Islands, Kalimantan, Sulawesi, Maluku and New Guinea (reference category). The variables name and the descriptive statistics is given in Table 1 and Table 2, respectively.

Table-1: Variable Names and Definitions

\begin{tabular}{|c|c|}
\hline Variables & Definitions \\
\hline \multicolumn{2}{|l|}{ Child Characteristics } \\
\hline$\overline{\text { Age }}$ & Child's age in completed years \\
\hline Girls & 1 if the child is a girl, 0 otherwise \\
\hline Son or daughter & $\begin{array}{l}1 \text { if the child is a son or daughter to the household, } \\
0 \text { otherwise }\end{array}$ \\
\hline \multicolumn{2}{|c|}{ Household Head's Characteristics } \\
\hline$\overline{\text { Age }}$ & Household head's age in completed years \\
\hline Female & 1 if household head is female, 0 otherwise \\
\hline \multicolumn{2}{|c|}{ Household Head's Education } \\
\hline Not Completed Primary & 1 if not completed primary, 0 otherwise (reference) \\
\hline Completed Primary & 1 if completed primary, 0 otherwise \\
\hline Junior Secondary & 1 if completed junior high school, 0 otherwise \\
\hline Senior Secondary & 1 if completed senior high school, 0 otherwise \\
\hline Tertiary Education & 1 if completed tertiary education, 0 otherwise \\
\hline \multicolumn{2}{|c|}{ Household Head's Employment } \\
\hline Self-Employed & 1 if occupation is self-employed, 0 otherwise \\
\hline Employer & (reference) \\
\hline Employee & 1 if occupation is employer, 0 otherwise \\
\hline Casual Worker & 1 if occupation is employee, 0 otherwise \\
\hline Unpaid Worker & 1 if occupation is casual worker, 0 otherwise \\
\hline Others & $\begin{array}{l}1 \text { if occupation is unpaid worker, } 0 \text { otherwise } \\
1 \text { if occupation is others, } 0 \text { otherwise }\end{array}$ \\
\hline
\end{tabular}




\begin{tabular}{|c|c|}
\hline$\frac{\text { Household Head Spouse's Education }}{\text { Not Completed Primary }}$ & \\
\hline Completed Primary & 1 if not completed primary, 0 otherwise (reference) \\
\hline Junior Secondary & 1 if completed primary, 0 otherwise \\
\hline Senior Secondary & 1 if completed junior high school, 0 otherwise \\
\hline Tertiary Education & $\begin{array}{l}1 \text { if completed senior high school, } 0 \text { otherwise } \\
1 \text { if completed tertiary education, } 0 \text { otherwise }\end{array}$ \\
\hline $\begin{array}{l}\text { Household Head Spouse's Employmen } \\
\text { Self-Employed }\end{array}$ & \\
\hline Employer & 1 if occupation is self-employed, 0 otherwise \\
\hline Employee & (reference) \\
\hline Casual Worker & 1 if occupation is employer, 0 otherwise \\
\hline Unpaid Worker & 1 if occupation is employee, 0 otherwise \\
\hline Others & $\begin{array}{l}1 \text { if occupation is casual worker, } 0 \text { otherwise } \\
1 \text { if occupation is unpaid worker , } 0 \text { otherwise }\end{array}$ \\
\hline Income (Indonesian Rupiah, IDR) & 1 if occupation is others, 0 otherwise \\
\hline $\begin{array}{l}\text { Household Income } \\
\text { Square of Household Income }\end{array}$ & \\
\hline & Household income (excluding children's earnings) \\
\hline$\underline{\text { Household Characteristics }}$ & Square Root of Household Income \\
\hline Birth Order & \\
\hline $\begin{array}{l}\text { Number of Children Aged Less Than } 5 \\
\text { years }\end{array}$ & Birth Order of the child in the household \\
\hline Number of Children Aged 6 to 9 years & Number of children aged less than 5 years in the \\
\hline Number of Children Aged 10 to 14 & household \\
\hline years & Number of children aged 6 to 9 years in the \\
\hline Number of Children Aged 15 to 17 & household \\
\hline years & Number of children aged 10 to 14 years in the \\
\hline Number of Adults (aged 18 years, & household \\
\hline above) & $\begin{array}{l}\text { Number of children aged } 15 \text { to } 17 \text { years in the } \\
\text { household }\end{array}$ \\
\hline Community Characteristics & Number of adults in the household \\
\hline Dwelling Ownership & \\
\hline Improved Drinking Water & $\begin{array}{l}\text { Percentage of households that own their dwelling in } \\
\text { each province }\end{array}$ \\
\hline Improved Sanitation & $\begin{array}{l}\text { Percentage of households that have improved } \\
\text { drinking water source in each province }\end{array}$ \\
\hline Source of Electricity & $\begin{array}{l}\text { Percentage of households that have improved } \\
\text { sanitation facility in each province }\end{array}$ \\
\hline Number of Schools & Percentage of households that have improved their \\
\hline Student-teacher Ratios & source of electricity in each province \\
\hline Gross Regional Domestic Product & Number of schools in each province \\
\hline Telephone & Ratios of student-teacher in each province \\
\hline Computer & GRDP per capita in each province \\
\hline & 1 if households have a telephone, 0 otherwise \\
\hline & 1 if households have a computer, 0 otherwise \\
\hline
\end{tabular}




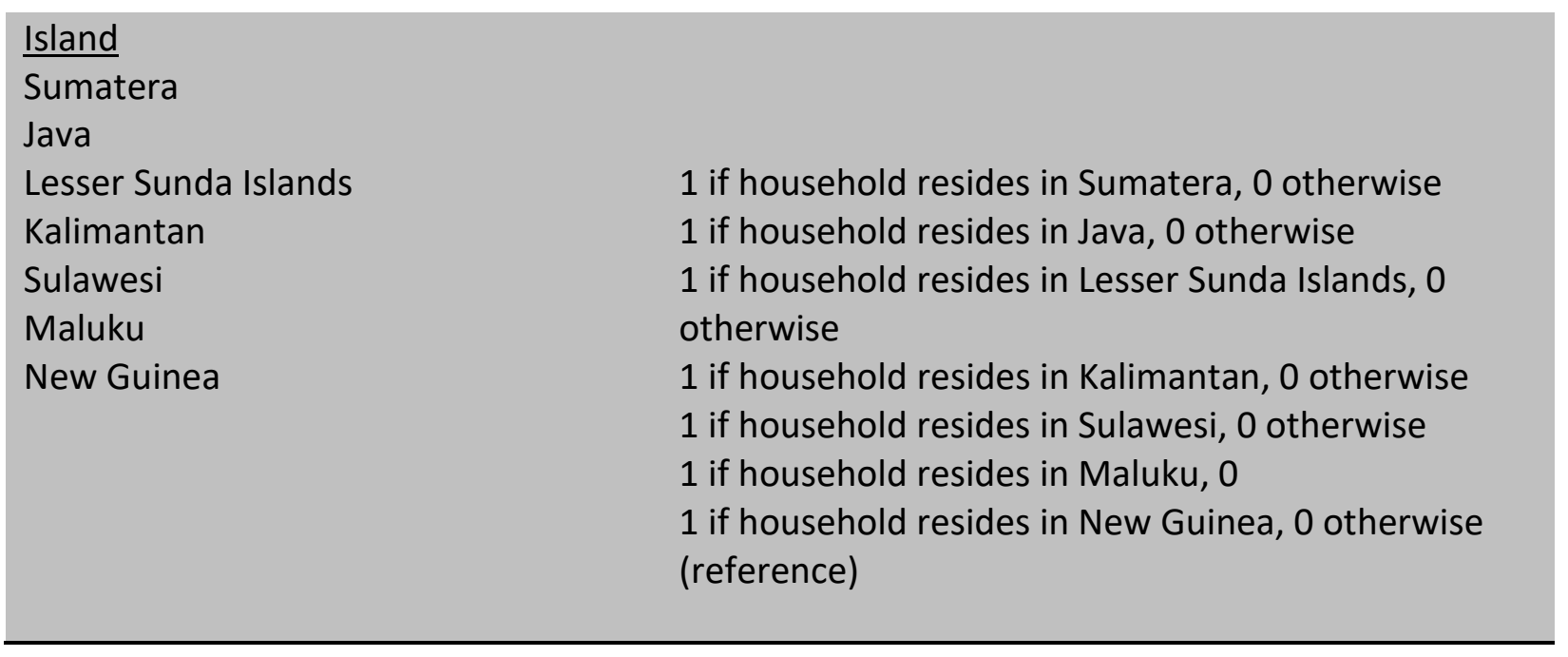

Table-2: Descriptive Statistics, SUSENAS 2007.

\begin{tabular}{|l|c|c|c|c|}
\hline & $\begin{array}{c}\text { School } \\
\text { Only }\end{array}$ & $\begin{array}{c}\text { School } \\
\text { and Work }\end{array}$ & Work Only & $\begin{array}{c}\text { Neither } \\
\text { Work nor } \\
\text { School }\end{array}$ \\
\hline Child Characteristics & 12.91 & 14.16 & 15.68 & 14.80 \\
Age & $(2.19)$ & $(2.07)$ & $(1.48)$ & $(1.95)$ \\
Girls & 0.48 & 0.37 & 0.30 & 0.39 \\
Biological child & $(0.50)$ & $(0.48)$ & $(0.46)$ & $(0.49)$ \\
Household Head's Characteristics & 0.92 & 0.87 & 0.88 & 0.92 \\
Age & $(0.26)$ & $(0.33)$ & $(0.33)$ & $(0.27)$ \\
Female Headed & & & & \\
Household Head's Education & 45.18 & 45.81 & 47.23 & 47.13 \\
Not Completed Primary & $(8.95)$ & $(9.56)$ & $(10.20)$ & $(9.56)$ \\
Completed Primary & 0.001 & 0.001 & 0.004 & 0.001 \\
& $(0.03)$ & $(0.03)$ & $(0.02)$ & $(0.03)$ \\
Junior Secondary & & & & \\
Senior Secondary & 0.04 & 0.08 & 0.14 & 0.10 \\
Tertiary Education & $(0.20)$ & $(0.28)$ & $(0.35)$ & $(0.30)$ \\
Household Head's Employment & 0.47 & 0.52 & 0.69 & 0.67 \\
Self-Employed & $(0.50)$ & $(0.50)$ & $(0.46)$ & $(0.47)$ \\
Employer & 0.17 & 0.17 & 0.10 & 0.12 \\
& $(0.37)$ & $(0.38)$ & $(0.30)$ & $(0.32)$ \\
& 0.23 & 0.17 & 0.06 & 0.10 \\
& $(0.42)$ & $(0.38)$ & $(0.23)$ & $(0.30)$ \\
& 0.09 & 0.06 & 0.01 & 0.02 \\
& $(0.29)$ & $(0.24)$ & $(0.12)$ & $(0.13)$ \\
& 0.37 & 0.13 & 0.18 & 0.27 \\
& $(0.48)$ & $(0.48)$ & $(0.49)$ & $(0.48)$ \\
\hline
\end{tabular}




\begin{tabular}{|l|c|c|c|c|}
\hline Employee & 0.33 & 0.16 & 0.17 & 0.28 \\
& $(0.47)$ & $(0.37)$ & $(0.38)$ & $(0.45)$ \\
Casual Worker & 0.01 & 0.01 & 0.01 & 0.02 \\
& $(0.12)$ & $(0.11)$ & $(0.12)$ & $(0.15)$ \\
Unpaid Worker & 0.01 & 0.02 & 0.01 & 0.01 \\
Others & $(0.10)$ & $(0.14)$ & $(0.12)$ & $(0.10)$ \\
& 0.03 & 0.03 & 0.04 & 0.05 \\
Spouse's Characteristics & $(0.18)$ & $(0.16)$ & $(0.19)$ & $(0.22)$ \\
Spouse's Education & & & & \\
Not Completed Primary & & & & \\
& 0.07 & 0.12 & 0.20 & 0.14 \\
Completed Primary & $(0.25)$ & $(0.33)$ & $(0.40)$ & $(0.35)$ \\
& 0.52 & 0.55 & 0.68 & 0.69 \\
Junior Secondary & $(0.50)$ & $(0.50)$ & $(0.47)$ & $(0.46)$ \\
Senior Secondary & 0.17 & 0.16 & 0.08 & 0.10 \\
& $(0.38)$ & $(0.37)$ & $(0.27)$ & $(0.30)$ \\
Tertiary Education & 0.18 & 0.13 & 0.03 & 0.06 \\
& $(0.38)$ & $(0.33)$ & $(0.18)$ & $(0.23)$ \\
Spouse's Employment & 0.06 & 0.04 & 0.01 & 0.01 \\
Self-Employed & $(0.25)$ & $(0.20)$ & $(0.11)$ & $(0.10)$ \\
& & & & \\
& 0.10 & 0.06 & 0.07 & 0.09 \\
\hline
\end{tabular}

Table-2: Descriptive Statistics, SUSENAS 2007 (continued).

\begin{tabular}{|l|c|c|c|c|}
\hline & $\begin{array}{c}\text { School } \\
\text { Only }\end{array}$ & $\begin{array}{c}\text { School } \\
\text { and Work }\end{array}$ & Work Only & $\begin{array}{c}\text { Neither } \\
\text { Work nor } \\
\text { School }\end{array}$ \\
\hline Employer & 0.08 & 0.21 & 0.10 & 0.06 \\
Casual Worker & $(0.27)$ & $(0.41)$ & $(0.30)$ & $(0.24)$ \\
Unpaid Worker & 0.12 & 0.06 & 0.07 & 0.10 \\
Others & $(0.33)$ & $(0.24)$ & $(0.26)$ & $(0.30)$ \\
Income (Indonesian Rupiah, IDR) & 0.01 & 0.01 & 0.01 & 0.01 \\
Household Income & $(0.08)$ & $(0.08)$ & $(0.10)$ & $(0.10)$ \\
Square of Household Income & 0.25 & 0.52 & 0.46 & 0.25 \\
Household Characteristics & $(0.44)$ & $(0.50)$ & $(0.50)$ & $(0.43)$ \\
Birth Order & 0.44 & 0.14 & 0.29 & 0.49 \\
& $(0.50)$ & $(0.35)$ & $(0.45)$ & $(0.50)$ \\
Number of Children Aged 0-5 & 1.12 & 0.63 & 0.50 & 0.74 \\
& $(1.51)$ & $(1.51)$ & $(0.88)$ & $(0.94)$ \\
& 3.52 & 2.68 & 1.03 & 1.44 \\
& $(20.00)$ & $(28.14)$ & $(6.22)$ & $(7.99)$ \\
& & & & \\
& 2.28 & 2.65 & 2.87 & 2.63 \\
& $(1.16)$ & $(1.40)$ & $(1.44)$ & $(1.30)$ \\
& 0.49 & 0.52 & 0.53 & 0.51 \\
& $(0.68)$ & $(0.73)$ & $(0.74)$ & $(0.70)$ \\
\hline
\end{tabular}


INTERNATIONAL JOURNAL OF ACADEMIC RESEARCH IN BUSINESS AND SOCIAL SCIENCES Vol. 9, No. 9, September, 2019, E-ISSN: 2222-6990 @ 2019 HRMARS

\begin{tabular}{|l|c|c|c|c|}
\hline Number of Children Aged 6-9 & 0.45 & 0.52 & 0.50 & 0.48 \\
Number of Children Aged 10-14 & $(0.62)$ & $90.68)$ & $(0.65)$ & $(0.63)$ \\
& 0.49 & 0.64 & 0.73 & 063 \\
Number of Children Aged 15-17 & $(0.65)$ & $(0.75)$ & $(0.78)$ & $(0.73)$ \\
Number of Adults & 0.33 & 0.32 & 0.28 & 0.29 \\
& $(0.55)$ & $(0.54)$ & $(0.50)$ & $(0.51)$ \\
Rural & 2.76 & 2.72 & 2.83 & 2.92 \\
Facilities & $(1.08)$ & $(1.05)$ & $(1.11)$ & $(1.15)$ \\
Owning a Dwelling & 0.62 & 0.81 & 0.82 & 0.71 \\
& $(0.48)$ & $(0.39)$ & $(0.39)$ & $(0.45)$ \\
Improved Drinking Water & & & & \\
Improved Sanitation & 77.08 & 77.09 & 78.22 & 78.02 \\
& $(8.55)$ & $(7.89)$ & $(7.80)$ & $(7.95)$ \\
Source of Electricity & 47.27 & 47.95 & 47.12 & 46.74 \\
& $(8.44)$ & $(7.26)$ & $(7.80)$ & $(8.39)$ \\
Number of Schools & 40.08 & 40.25 & 38.06 & 40.67 \\
& $(11.64)$ & $(12.65)$ & $(12.47)$ & $(10.67)$ \\
Student-teacher Ratio & 85.01 & 82.32 & 81.38 & 86.44 \\
& $(14.02)$ & $(14.92)$ & $(16.82)$ & $(14.03)$ \\
Gross Regional Domestic Product & 9.09 & 8.98 & 8.97 & 9.26 \\
(GRDP) & $(1.02)$ & $(0.90)$ & $(0.99)$ & $(1.07)$ \\
Telephone & 14.09 & 14.29 & 14.03 & 14.20 \\
Computer & $(2.31)$ & $(2.43)$ & $(2.29)$ & $(2.25)$ \\
& 15.78 & 12.77 & 13.84 & 14.69 \\
& $(14.20)$ & $(9.03)$ & $(11.88)$ & $(12.36)$ \\
& 0.13 & 0.08 & 0.03 & 0.04 \\
& $(0.34)$ & $(0.27)$ & $(0.18)$ & $(0.19)$ \\
& 0.07 & 0.04 & 0.01 & 0.01 \\
& $(0.25)$ & $(0.21)$ & $(0.11)$ & $(0.12)$ \\
& & & & \\
& & & & \\
\hline
\end{tabular}

Table-2: Descriptive Statistics, SUSENAS 2007 (continued).

\begin{tabular}{|l|c|c|c|c|}
\hline & $\begin{array}{c}\text { School } \\
\text { Only }\end{array}$ & $\begin{array}{c}\text { School } \\
\text { and Work }\end{array}$ & Work Only & $\begin{array}{c}\text { Neither } \\
\text { Work nor } \\
\text { School }\end{array}$ \\
\hline Island & 0.33 & 0.34 & 0.26 & 0.25 \\
Sumatera & $(0.47)$ & $(0.47)$ & $(0.44)$ & $(0.43)$ \\
Lesser Sunda Islands & 0.28 & 0.14 & 0.22 & 0.39 \\
Kalimantan & $(0.45)$ & $(0.35)$ & $(0.41)$ & $(0.49)$ \\
Sulawesi & 0.07 & 0.12 & 0.11 & 0.06 \\
& $(0.26)$ & $(0.33)$ & $(0.32)$ & $(0.23)$ \\
Maluku & 0.12 & 0.09 & 0.13 & 0.10 \\
& $(0.32)$ & $(0.28)$ & $(0.34)$ & $(0.30)$ \\
& 014 & 0.23 & 0.20 & 0.15 \\
& $(0.35)$ & $(0.42)$ & $(0.40)$ & $(0.36)$ \\
\hline
\end{tabular}




\begin{tabular}{|l|c|c|c|c|}
\hline & $(0.18)$ & $(0.21)$ & $(0.15)$ & $(0.13)$ \\
& 0.03 & 0.03 & 0.05 & 0.04 \\
& $(0.16)$ & $(0.18)$ & $(0.21)$ & $(0.19)$ \\
\hline Number of Observations & 128,150 & 9,401 & 10,071 & 7,701 \\
\hline
\end{tabular}

Notes: Standard deviations are reported in brackets.

\section{Econometric Specification}

The multinomial logit is an appropriate technique of estimation to study the interaction of child labor and child schooling participation/non-participation rates. Multinomial logit estimation simultaneously analyses four possibilities of child's activity. In addition, such extension has been made possible by the recent availability on child participation rates than what was available previously. A similar approach is used by Psacharopoulos (1997), Cartwright and Patrinos (1999), Deb and Rosati (2001), Ray and Lancaster (2003) and Khanam (2004). Multinomial logit estimation is similar to the logistic regression model, except that the probability distribution of the response is multinomial instead of binomial (Moyi, 2011). The model assumes that the choice of outcomes must be independent. In addition, it requires that the inclusion or exclusion of categories does not affect the relative risks associated with the explanatory variables in the remaining categories. The advantage of using multinomial logit is that it permits the analysis of decisions across more than two categories, which allows for the determination of choice probabilities for different categories of child activity. Apart from the well-known drawbacks of the Independence of Irrelevant Alternatives (IIA), this approach is more appropriate than the probit or logit model that is conventionally used.

Households trying to maximize their utility face a choice between discrete options. Four mutually exclusive options are listed here: child attends school only, child works only, child attends work and school, and child neither goes to school nor work. Suppose there are numbers of children, $i=1,2,3, \ldots N$. Given four choices of categories, $j=1,2,3,4$, the multinomial logit assigns probabilities $P_{i j}$ to events characterized as " $i$ th $c h i l d$ in $j^{\text {th }}$ category". To estimate this model, the category of child attending school only is referred to as the "reference state". Therefore, the probabilities in the multinomial logit model can be specified as:

$$
\begin{aligned}
& \operatorname{Pr}\left(Y_{i}=j\right)=\frac{e^{\beta_{j}^{\prime} x_{i}}}{1+\sum_{k=1}^{j} e^{\beta_{k}^{\prime} x_{i}}} \\
& \operatorname{Pr}\left(Y_{i}=0\right)=\frac{1}{1+\sum_{k=1}^{j} e^{\beta_{k}^{\prime} x_{i}}} \quad \text { for } \mathrm{j}=1,2,3,4
\end{aligned}
$$

where, $\beta_{j}$ is a vector of coefficients and $x_{i}$ is a vector of conditioning explanatory variables. However, the coefficients of the multinomial logit model are difficult to interpret. Neither the sign nor the magnitude of the coefficients has a direct intuitive meaning. Hence, partial derivatives are calculated to interpret the effect of the independent variables on the probabilities of each category.

$$
\frac{\partial P_{j}}{\partial x_{i}}=P_{j}\left[\beta_{j}-\sum_{k=1}^{J} P_{k} \beta_{k}\right]
$$

where, $P$ is the probability of participation of each category. The log-probability function is: 


$$
\ln L=\sum_{i=1}^{n} \sum_{j=0}^{J} d_{i j} \ln \operatorname{Pr}\left(Y_{i}=j\right)
$$

Where, $d_{i j}=1$ if individual $i$ chooses alternative $j$, and $d_{i j}=0$ otherwise.

\section{Results and Discussion}

Percentages of correct predictions for each category are given in Table 3 . The percentage of correct prediction is greater than $50 \%$, which is $82.50 \%$. The Chi-squared value is also highly significant in each estimate in the year of the survey. The significance level of coefficients on the residual variable forms the basis of the exogeneity test. Therefore, the null hypothesis of the exogeneity of productivity variable was rejected.

Table 3: Percentages of Prediction for Each Child Use Categories.

\begin{tabular}{|c|c|c|c|c|c|}
\hline \multirow[t]{2}{*}{ Category } & \multicolumn{4}{|c|}{ Predicted (\%) } & \multirow{2}{*}{$\begin{array}{l}\text { Total } \\
\text { (n) }\end{array}$} \\
\hline & $\begin{array}{l}\text { School } \\
\text { Only }\end{array}$ & $\begin{array}{l}\text { School } \\
\text { and Work }\end{array}$ & Work Only & Neither & \\
\hline \multicolumn{6}{|l|}{ Actual } \\
\hline School Only & 83.9 & 5.7 & 5.5 & 4.9 & 128,150 \\
\hline School and Work & 42.5 & 31.8 & 21.4 & 4.3 & 9,401 \\
\hline Work Only & 32.1 & 15.4 & 43.1 & 9.4 & 10,071 \\
\hline $\begin{array}{l}\text { Neither work nor } \\
\text { School }\end{array}$ & 29.3 & 0.0 & 20.7 & 50.0 & 7,807 \\
\hline Total (n) & 127,451 & 9,498 & 10,571 & 7,807 & 155,327 \\
\hline
\end{tabular}

Notes:

aPercentages are given by the ration of number predicted in the category over total actual number which is calculated using expected percent correctly predicted (ePCP) which was proposed by Herron (1999). The percent correctly predicted simply gives what percentage of observations that we got right. For example, for the category "School Only" for example, percentage of correct prediction is $83.9 \%$ (107518/149615), and the row total should be equal to $100 \%$.

${ }^{\mathrm{b}}$ The concept is comparing the model to the null model (without variables (only intercepts) and this model will not explain anything and it will simply reproduce the marginal observed probabilities in the dataset. So, PCP - the null model will predict only the number of cases in the modal category right .In fact, the null model will predict everyone in the modal category as that is the way that it gets the most possible cases right foor sure.

cPercentage of correct predictions of child utilization categories $=82.50 \%$

There are three variables characterizing the child: age, gender, and relationship to the head of the household (Table 4). As found by Bonsang and Faye (2005) in their study of child labor in Senegal, the probability to work significantly increases as boys or girls get older. The probability of "work only", "school and work" and "neither work nor school" increases with age as opposed to the probability of "school only" (Table 4). One possible explanation of this result is the fact that as children grow up, their opportunity cost for "school only" increases, thus, they either "study and work", "work only" or being "idle". A study by Grootaert (1998) in Cote d'Ivoire, Cigno and Rosati (2002) in India and Khanam (2005) in Bangladesh find similar effects of age on the probability of "school and work" and "work only". Mixed effects of age on the probability of "work only" has been found by Cigno and Rosati where the probability 
of work only decreases for the children up to 8 years old, then increase at the age up to 12 years, and then decreases again. The result also confirms that older children are more likely to be in "neither work nor school", which is similar to findings in other developing countries. As stated by Khanam (2005), one reason for these children is the fact that they may be from very poor households and the households do not have much land or other productive resources to employ them. Thus, limited resources in the household to cover the costs of education have pulled out the children from school and stay at home. One other reason could be that the parents are illiterate and who do not understand the value of education well, so they keep the children at home to help them instead of sending them to school. There is no significant effect of age on the probability of "school and work" and the probability of "neither work nor school" among Mexican children as found by Levison et al. (2001).

The result also confirm that if a child is the son or daughter of the head of household, he or she is less likely to "school and work" and "work only", but more likely to be "idle" children. The coefficient shows a significant and positive effect on the probability of "neither work nor school" ( 0.5 percentage point), indicating that the son or daughter of the household head is also likely to be in "idle" category. 
INTERNATIONAL JOURNAL OF ACADEMIC RESEARCH IN BUSINESS AND SOCIAL SCIENCES

Vol. 9, No. 9, September, 2019, E-ISSN: 2222-6990 @ 2019 HRMARS

Table-4: Multinomial Logit (Marginal Effects) of Child Activities of All Working Children and by Gender, SUSENAS 2007.

\begin{tabular}{|c|c|c|c|c|c|c|c|c|c|}
\hline \multirow[t]{3}{*}{ Variables } & \multirow{2}{*}{\multicolumn{3}{|c|}{ All }} & \multicolumn{6}{|c|}{ Gender } \\
\hline & & & & \multicolumn{3}{|c|}{ Boys } & \multicolumn{3}{|c|}{ Girls } \\
\hline & $\begin{array}{c}\text { School and } \\
\text { Work }\end{array}$ & Work Only & Neither & $\begin{array}{c}\text { School and } \\
\text { Work }\end{array}$ & Work Only & Neither & $\begin{array}{c}\text { School and } \\
\text { Work }\end{array}$ & Work Only & Neither \\
\hline \multicolumn{10}{|l|}{ Age Groups } \\
\hline 10 to 12 years & $\begin{array}{c}-0.0247^{*} \\
(0.0017)\end{array}$ & $\begin{array}{c}-0.0865^{*} \\
(0.0029)\end{array}$ & $\begin{array}{c}-0.0322^{*} \\
(0.0018)\end{array}$ & $\begin{array}{c}-0.0256^{*} \\
(0.0025)\end{array}$ & $\begin{array}{l}-0.1054^{*} \\
(0.0044)\end{array}$ & $\begin{array}{c}-0.0330 * \\
(0.0027)\end{array}$ & $\begin{array}{c}-0.0215^{*} \\
(0.0023)\end{array}$ & $\begin{array}{l}-0.0606^{*} \\
(0.0037)\end{array}$ & $\begin{array}{c}-0.0314^{*} \\
(0.0025)\end{array}$ \\
\hline 15 to 17 years & $\begin{array}{l}0.0180 * \\
(0.0014)\end{array}$ & $\begin{array}{l}0.0779 * \\
(0.0016)\end{array}$ & $\begin{array}{l}0.0311^{*} \\
(0.0014)\end{array}$ & $\begin{array}{l}0.0161 * \\
(0.0021)\end{array}$ & $\begin{array}{l}0.0921 * \\
(0.0023)\end{array}$ & $\begin{array}{l}0.0329 * \\
(0.0019)\end{array}$ & $\begin{array}{l}0.0183^{*} \\
(0.0020)\end{array}$ & $\begin{array}{l}0.0585^{*} \\
(0.0021)\end{array}$ & $\begin{array}{l}0.0294^{*} \\
(0.0019)\end{array}$ \\
\hline \multicolumn{10}{|l|}{ Child } \\
\hline \multirow{3}{*}{ Girls } & $-0.0184^{*}$ & $-0.0317^{*}$ & $-0.0084^{*}$ & - & - & - & - & - & - \\
\hline & $(0.0012)$ & $(0.0012)$ & $(0.0011)$ & & & & & & \\
\hline & $-0.0329 *$ & $-0.0346^{*}$ & $0.0047^{* *}$ & $-0.0201^{*}$ & $-0.0243^{*}$ & 0.0028 & $-0.0393 *$ & $-0.0381^{*}$ & $0.0070 * *$ \\
\hline Biological Child & $(0.0019)$ & $(0.0019)$ & $(0.0021)$ & $(0.0030)$ & $(0.0031)$ & $(0.0030)$ & $(0.0022)$ & $(0.0021)$ & (0.0029) \\
\hline \multicolumn{10}{|l|}{ Household Head's } \\
\hline Characteristics & $-0.0002^{*}$ & $-0.0004^{*}$ & -0.00002 & -0.0001 & $-0.0002 * *$ & 0.0001 & $-0.0004^{*}$ & $-0.0007^{*}$ & -0.0001 \\
\hline \multirow[t]{2}{*}{ Age } & $(0.0001)$ & $(0.0001)$ & $(0.0001)$ & $(0.0001)$ & $(0.0001)$ & $(0.0001)$ & $(0.0001)$ & $(0.0001)$ & $(0.0001)$ \\
\hline & -0.0035 & -0.0387 & 0.0185 & -0.0253 & -0.0206 & 0.0122 & 0.0663 & -0.5020 & 0.0755 \\
\hline Female Headed & $(0.0219)$ & $(0.0284)$ & $(0.0173)$ & $(0.0368)$ & $(0.0367)$ & $(0.0242)$ & $(0.2017)$ & $(0.8019)$ & $(0.1636)$ \\
\hline \multicolumn{10}{|l|}{ Household Head's } \\
\hline Education & $-0.0089 *$ & $-0.0176^{*}$ & $-0.0127 *$ & $-0.0110^{*}$ & $-0.0176^{*}$ & $-0.0144 *$ & -0.0052 & $-0.0182^{*}$ & $-0.0110 *$ \\
\hline \multirow[t]{2}{*}{ Completed Primary } & $(0.0025)$ & $(0.0021)$ & $(0.0021)$ & $(0.0035)$ & $(0.0031)$ & $(0.0030)$ & $(0.0036)$ & $(0.0025)$ & $(0.0029)$ \\
\hline & -0.0034 & $-0.0504^{*}$ & $-0.0286^{*}$ & -0.0049 & $-0.0581^{*}$ & $-0.0299 *$ & 0.0003 & $-0.0401^{*}$ & $-0.0275^{*}$ \\
\hline \multirow[t]{2}{*}{ Junior Secondary } & $(0.0028)$ & $(0.0027)$ & $(0.0026)$ & $(0.0040)$ & $(0.0040)$ & $(0.0037)$ & $(0.0040)$ & $(0.0034)$ & $(0.0036)$ \\
\hline & $-0.0059 * *$ & $-0.0709 *$ & $-0.0317^{*}$ & -0.0060 & $-0.0854^{*}$ & $-0.0375^{*}$ & -0.0032 & $-0.0522^{*}$ & $-0.0255^{*}$ \\
\hline \multirow[t]{2}{*}{ Senior Secondary } & $(0.0030)$ & $(0.0032)$ & $(0.0028)$ & $(0.0043)$ & $(0.0048)$ & $(0.0041)$ & $(0.0042)$ & $(0.0039)$ & $(0.0038)$ \\
\hline & 0.0011 & $-0.0737^{*}$ & $-0.0434 *$ & 0.0011 & $-0.1310 *$ & $-0.0400 *$ & 0.0046 & $-0.0456 *$ & $-0.0409 *$ \\
\hline
\end{tabular}


INTERNATIONAL JOURNAL OF ACADEMIC RESEARCH IN BUSINESS AND SOCIAL SCIENCES Vol. 9, No. 9, September, 2019, E-ISSN: 2222-6990 @ 2019 HRMARS

\begin{tabular}{|l|c|c|c|c|c|c|c|c|c|}
\hline Tertiary Education & $(0.0041)$ & $(0.0057)$ & $(0.0050)$ & $(0.0065)$ & $(0.0124)$ & $(0.0073)$ & $(0.0052)$ & $(0.0058)$ & $(0.0067)$ \\
Household Head's & & & & & & & \\
Employment & $0.0285^{*}$ & $0.0068^{*}$ & $-0.0182^{*}$ & $0.0355^{*}$ & $0.0080^{*}$ & $-0.0227^{*}$ & $0.0173^{*}$ & 0.0007 & $-0.0126^{*}$ \\
Employer & $(0.0021)$ & $(0.0020)$ & $(0.0018)$ & $(0.0031)$ & $(0.0030)$ & $(0.0025)$ & $(0.0027)$ & $(0.0024)$ & $(0.0024)$ \\
& -0.0016 & $-0.0067^{*}$ & $0.0034^{* *}$ & 0.0007 & $0.0124^{*}$ & 0.0027 & -0.0041 & 0.0002 & $0.0039^{* * *}$ \\
Employee & $(0.0022)$ & $(0.0020)$ & $(0.0015)$ & $(0.0033)$ & $(0.0029)$ & $(0.0022)$ & $(0.0029)$ & $(0.0024)$ & $(0.0021)$ \\
& & & & & & & & & \\
\hline
\end{tabular}

Table-4: Multinomial Logit (Marginal Effects) of Child Activities of All Working Children and by Gender, SUSENAS 2007 (continued).

\begin{tabular}{|c|c|c|c|c|c|c|c|c|c|}
\hline \multirow[t]{3}{*}{ Variables } & \multirow{2}{*}{\multicolumn{3}{|c|}{ All }} & \multicolumn{6}{|c|}{ Gender } \\
\hline & & & & \multicolumn{3}{|c|}{ Boys } & \multicolumn{3}{|c|}{ Girls } \\
\hline & $\begin{array}{c}\text { School and } \\
\text { Work }\end{array}$ & Work Only & Neither & $\begin{array}{c}\text { School and } \\
\text { Work }\end{array}$ & Work Only & Neither & $\begin{array}{c}\text { School and } \\
\text { Work }\end{array}$ & Work Only & Neither \\
\hline Casual Worker & $\begin{array}{l}0.0197^{*} \\
(0.0056)\end{array}$ & $\begin{array}{c}0.0079 \\
(0.0051)\end{array}$ & $\begin{array}{c}0.0067 * * * \\
(0.0039)\end{array}$ & $\begin{array}{l}0.0254^{*} \\
(0.0081)\end{array}$ & $\begin{array}{c}0.0087 \\
(0.0076)\end{array}$ & $\begin{array}{c}0.0108^{* *} \\
(0.0054)\end{array}$ & $\begin{array}{c}0.0129 * * * \\
(0.0076)\end{array}$ & $\begin{array}{c}0.0042 \\
(0.0063)\end{array}$ & $\begin{array}{c}0.0013 \\
(0.0057)\end{array}$ \\
\hline Unpaid Worker & $\begin{array}{l}0.0295^{*} \\
(0.0047)\end{array}$ & $\begin{array}{c}0.0031 \\
(0.0053)\end{array}$ & $\begin{array}{c}-0.0145^{*} \\
(0.0053)\end{array}$ & $\begin{array}{l}0.0318^{*} \\
(0.0071)\end{array}$ & $\begin{array}{c}0.0056 \\
(0.0080)\end{array}$ & $\begin{array}{c}-0.0283^{*} \\
(0.0083)\end{array}$ & $\begin{array}{l}0.0235^{*} \\
(0.0060)\end{array}$ & $\begin{array}{c}-0.0033 \\
(0.0065)\end{array}$ & $\begin{array}{c}-0.0001 \\
(0.0066)\end{array}$ \\
\hline Others & $\begin{array}{l}0.0143^{*} \\
(0.0040)\end{array}$ & $\begin{array}{l}0.0097^{*} \\
(0.0035)\end{array}$ & $\begin{array}{c}0.0025 \\
(0.0029)\end{array}$ & $\begin{array}{l}0.0178^{*} \\
(0.0060)\end{array}$ & $\begin{array}{c}0.0054 \\
(0.0055)\end{array}$ & $\begin{array}{c}0.0035 \\
(0.0041)\end{array}$ & $\begin{array}{c}0.0099 * * * \\
(0.0051)\end{array}$ & $\begin{array}{l}0.0112 * \\
(00040)\end{array}$ & $\begin{array}{c}0.0011 \\
(0.0041)\end{array}$ \\
\hline $\begin{array}{l}\frac{\text { Spouse's }}{\text { Characteristics }} \\
\text { Spouse's Education }\end{array}$ & & & & & & & & & \\
\hline Completed Primary & $\begin{array}{c}-0.0085^{*} \\
(0.0021)\end{array}$ & $\begin{array}{c}-0.0236^{*} \\
(0.0018)\end{array}$ & $\begin{array}{c}-0.0085^{*} \\
(0.0018)\end{array}$ & $\begin{array}{c}-0.0071^{* *} \\
(0.0030)\end{array}$ & $\begin{array}{c}-0.0281 * \\
(0.0027)\end{array}$ & $\begin{array}{c}-0.0054^{* *} \\
(0.0026)\end{array}$ & $\begin{array}{r}-0.0100^{*} \\
(0.0030)\end{array}$ & $\begin{array}{c}-0.0175^{*} \\
(0.0023)\end{array}$ & $\begin{array}{c}-0.0123 * \\
(0.0025)\end{array}$ \\
\hline Junior Secondary & $\begin{array}{c}-0.0053^{* *} \\
(0.0026)\end{array}$ & $\begin{array}{l}-0.0580 * \\
(0.0027)\end{array}$ & $\begin{array}{l}-0.0272 * \\
(0.0025)\end{array}$ & $\begin{array}{l}-0.0040 \\
(0.0038)\end{array}$ & $\begin{array}{l}-0.0651^{*} \\
(0.0040)\end{array}$ & $\begin{array}{c}-0.0239 * \\
(0.0036)\end{array}$ & $\begin{array}{c}-0.0060 * * * \\
(0.0036)\end{array}$ & $\begin{array}{l}-0.0479 * \\
(0.0035)\end{array}$ & $\begin{array}{c}-0.0315 * \\
(0.0035)\end{array}$ \\
\hline Senior Secondary & $\begin{array}{c}-0.0063^{* *} \\
(0.0029)\end{array}$ & $\begin{array}{l}-0.0771^{*} \\
(0.0036)\end{array}$ & $\begin{array}{l}-0.0361 * \\
(0.0031)\end{array}$ & $\begin{array}{c}-0.0036 \\
(0.0043)\end{array}$ & $\begin{array}{l}-0.0870^{*} \\
(0.0054)\end{array}$ & $\begin{array}{c}-0.0352^{*} \\
(0.0045)\end{array}$ & $\begin{array}{c}-0.0075 * * * \\
(0.0039)\end{array}$ & $\begin{array}{l}-0.0609 * \\
(0.0044)\end{array}$ & $\begin{array}{c}-0.0374 * \\
(0.0042)\end{array}$ \\
\hline Tertiary Education & $\begin{array}{c}-0.0050 \\
(0.0046)\end{array}$ & $\begin{array}{l}-0.0648^{*} \\
(0.0062)\end{array}$ & $\begin{array}{l}-0.0435^{*} \\
(0.0060)\end{array}$ & $\begin{array}{l}-0.0068 \\
(0.0078)\end{array}$ & $\begin{array}{l}-0.1084^{*} \\
(0.0142)\end{array}$ & $\begin{array}{c}-0.0422^{*} \\
(0.0092)\end{array}$ & $\begin{array}{l}-0.0035 \\
(0.0055)\end{array}$ & $\begin{array}{c}-0.0521^{*} \\
(0.0062)\end{array}$ & $\begin{array}{c}-0.0398^{*} \\
(0.0076)\end{array}$ \\
\hline
\end{tabular}


INTERNATIONAL JOURNAL OF ACADEMIC RESEARCH IN BUSINESS AND SOCIAL SCIENCES Vol. 9, No. 9, September, 2019, E-ISSN: 2222-6990 @ 2019 HRMARS

\begin{tabular}{|c|c|c|c|c|c|c|c|c|c|}
\hline Spouse's & & & & & & & & & \\
\hline Employment & $0.0716^{*}$ & $0.0130 *$ & $-0.0188^{*}$ & $0.0607^{*}$ & $0.0080 * * *$ & $-0.0243^{*}$ & $0.0787^{*}$ & $0.0163^{*}$ & $-0.0122^{*}$ \\
\hline Employer & $(0.0028)$ & $(0.0029)$ & $(0.0028)$ & $(0.0041)$ & $(0.0044)$ & $(0.0039)$ & $(0.0038)$ & $(0.0034)$ & (0.0039) \\
\hline & -0.0057 & 0.0190* & $0.0058 * *$ & $-0.0107 * *$ & $0.0142^{*}$ & 0.0047 & 0.0001 & $0.0201^{*}$ & $0.0083^{* *}$ \\
\hline Employee & $(0.0035)$ & $(0.0031)$ & $(0.0025)$ & (0.0052) & $(0.0048)$ & $(0.0036)$ & $(0.0045)$ & $(0.0035)$ & $(0.0036)$ \\
\hline & $0.0179 * *$ & $0.0274 *$ & -0.0017 & $0.0208 * * *$ & $0.0369 *$ & -0.0066 & 0.0106 & $0.0145^{* * *}$ & 0.0043 \\
\hline Casual Worker & $(0.0080)$ & $(0.0065)$ & $(0.0059)$ & $(0.0111)$ & $(0.0098)$ & $(0.0084)$ & $(0.0118)$ & $(0.0080)$ & $(0.0083)$ \\
\hline & $0.0424^{*}$ & $0.0153 *$ & $-0.0100^{*}$ & $0.0385^{*}$ & $0.0128^{*}$ & $-0.0155^{*}$ & $0.0458 *$ & $0.0168^{*}$ & -0.0032 \\
\hline Unpaid Worker & $(0.0028)$ & $(0.0026)$ & $(0.0023)$ & (0.0039) & $(0.0038)$ & $(0.0032)$ & $(0.0038)$ & $(0.0032)$ & $(0.0033)$ \\
\hline & $-0.0297^{*}$ & $-0.0071^{*}$ & $0.0064^{*}$ & $-0.0309 *$ & $-0.0070 * * *$ & 0.0020 & $-0.0334^{*}$ & $-0.0092^{*}$ & $0.0123^{*}$ \\
\hline Others & $(0.0028)$ & $(0.0024)$ & $(0.0020)$ & $(0.0040)$ & $(0.0037)$ & $(0.0028)$ & $(0.0041)$ & $(0.0030)$ & $(0.0028)$ \\
\hline Income & & & & & & & & & \\
\hline Indonesian & $0.0032^{*}$ & $-0.0105^{*}$ & $-0.0110^{*}$ & 0.0004 & $-0.0188 *$ & $-0.0119 *$ & $0.0050 *$ & $-0.0038^{*}$ & $-0.0099 *$ \\
\hline$\underline{\text { Rupiah, (DR) }}$ & $(0.0009)$ & $(0.0011)$ & (00010) & $(0.0016)$ & $(0.0020)$ & $(0.0014)$ & (0.0009) & $(0.0011)$ & $(0.0013$ \\
\hline Household Income & & & & & & & & & \\
\hline
\end{tabular}

Table-4: Multinomial Logit (Marginal Effects) of Child Activities of All Working Children and by Gender, SUSENAS 2007 (continued).

\begin{tabular}{|c|c|c|c|c|c|c|c|c|c|}
\hline \multirow[t]{3}{*}{ Variables } & \multirow{2}{*}{\multicolumn{3}{|c|}{ All }} & \multicolumn{6}{|c|}{ Gender } \\
\hline & & & & \multicolumn{3}{|c|}{ Boys } & \multicolumn{3}{|c|}{ Girls } \\
\hline & $\begin{array}{c}\text { School and } \\
\text { Work }\end{array}$ & Work Only & Neither & $\begin{array}{c}\text { School and } \\
\text { Work }\end{array}$ & Work Only & Neither & $\begin{array}{c}\text { School and } \\
\text { Work }\end{array}$ & Work Only & Neither \\
\hline $\begin{array}{l}\text { Square of } \mathrm{HH} \\
\text { Income }\end{array}$ & $\begin{array}{c}0.0001 \\
(0.00004)\end{array}$ & $\begin{array}{c}0.0003^{*} \\
(0.00004)\end{array}$ & $\begin{array}{c}0.0003^{*} \\
(0.00004)\end{array}$ & $\begin{array}{c}0.0001 \\
(0.0001)\end{array}$ & $\begin{array}{l}0.0006^{*} \\
(0.0001)\end{array}$ & $\begin{array}{l}0.0003^{*} \\
(0.0001)\end{array}$ & $\begin{array}{l}-0.00003 \\
(0.00003)\end{array}$ & $\begin{array}{c}0.0001^{*} \\
(0.00003)\end{array}$ & $\begin{array}{c}0.0002^{*} \\
(0.00005)\end{array}$ \\
\hline Household & 0.0047* & $0.0331^{*}$ & $0.0038 * *$ & $0.0054 * *$ & $0.0456 *$ & 0.0004 & 0.0034 & 0.0181* & $0.0080 *$ \\
\hline Characteristics & (0.0017) & $(0.0021)$ & (0.0017) & (0.0024) & (0.0031) & $(0.0024)$ & $(0.0022)$ & $(0.0025)$ & $(0.0024)$ \\
\hline Birth Order & $\begin{array}{c}-0.0001 \\
(0.0019) \\
0.0004\end{array}$ & $\begin{array}{l}-0.0190^{*} \\
(0.0022) \\
-0.0253^{*}\end{array}$ & $\begin{array}{c}0.0023 \\
(0.0019) \\
0.0012\end{array}$ & $\begin{array}{l}-0.0019 \\
(0.0027) \\
-0.0003\end{array}$ & $\begin{array}{l}-0.0285^{*} \\
(0.0034) \\
-0.0357^{*}\end{array}$ & $\begin{array}{c}0.0072 * \\
(0.0027) \\
0.0044\end{array}$ & $\begin{array}{c}0.0015 \\
(0.0025) \\
0.0014\end{array}$ & $\begin{array}{c}-0.0082^{*} \\
(0.0027) \\
-0.0126^{*}\end{array}$ & $\begin{array}{l}-0.0035 \\
(0.0027) \\
-0.0028\end{array}$ \\
\hline
\end{tabular}


INTERNATIONAL JOURNAL OF ACADEMIC RESEARCH IN BUSINESS AND SOCIAL SCIENCES Vol. 9, No. 9, September, 2019, E-ISSN: 2222-6990 @ 2019 HRMARS

\begin{tabular}{|c|c|c|c|c|c|c|c|c|c|}
\hline \multirow{3}{*}{$\begin{array}{l}\text { Child Aged 0-5 } \\
\text { years }\end{array}$} & $(0.0019)$ & $(0.0023)$ & (0.0019) & $(0.0028)$ & $(0.0034)$ & $(0.0027)$ & $(0.0025)$ & $(0.0028)$ & $(0.0027)$ \\
\hline & -0.0001 & $-0.0242 *$ & $0.0033^{* * *}$ & 0.0009 & $-0.0343^{*}$ & $0.0079 *$ & -0.0008 & $-0.0116^{*}$ & -0.0022 \\
\hline & $(0.0016)$ & $(0.0022)$ & (0.0017) & $(0.0023)$ & $(0.0033)$ & $(0.0024)$ & $(0.0021)$ & $(0.0026)$ & (0.0024) \\
\hline \multirow{3}{*}{$\begin{array}{l}\text { Child Aged 6-9 } \\
\text { years }\end{array}$} & -0.0015 & $-0.0086^{*}$ & $0.0041^{*}$ & -0.0019 & $-0.0136^{*}$ & $0.0074^{*}$ & -0.0010 & $-0.0031 * * *$ & 0.0001 \\
\hline & $(0.0011)$ & $(0.0014)$ & (0.0011) & $(0.0017)$ & $(0.0022)$ & $(0.0016)$ & $(0.0015)$ & (0.0017) & (0.0016) \\
\hline & -0.0075 & $-0.0031^{*}$ & $0.0053^{*}$ & $-0.0079 *$ & $-0.0029 *$ & $0.0071 *$ & $-0.0064^{*}$ & $-0.0025^{*}$ & $0.0032^{*}$ \\
\hline \multirow{4}{*}{$\begin{array}{l}\text { Child Aged 10-14 } \\
\text { years } \\
\text { Child Aged 15-17 } \\
\text { years } \\
\text { Number of Adults }\end{array}$} & $(0.0006)$ & $(0.0006)$ & (0.0005) & (0.0009) & (0.0009) & $(0.0008)$ & $(0.0008)$ & (0.0007) & (0.0007) \\
\hline & $0.0170 *$ & $0.0105^{*}$ & $0.0049 *$ & $0.0216 *$ & $0.0187^{*}$ & 0.0029 & $0.0104^{*}$ & 0.0008 & $0.0071^{*}$ \\
\hline & $(0.0017)$ & $(0.0016)$ & $(0.0013)$ & $(0.0025)$ & $(0.0025)$ & (0.0019) & $(0.0022)$ & (0.0019) & (0.0019) \\
\hline & $-0.0004 *$ & $-0.0003 * *$ & $-0.0006 *$ & 0.0001 & $0.0034 * * *$ & $-0.0005^{*}$ & $-0.0008 *$ & $-0.0008 *$ & $-0.0007^{*}$ \\
\hline \multirow[t]{2}{*}{ Rural } & $(0.0001)$ & $(0.0001)$ & $(0.0001)$ & $(0.0002)$ & $(0.0002)$ & $(0.0002)$ & $(0.0002)$ & $(0.0002)$ & $(0.0002)$ \\
\hline & $0.0003 * *$ & -0.0001 & $-0.0004^{*}$ & $0.0004 * *$ & -0.0002 & $-0.0004^{*}$ & 0.0001 & 0.0001 & $-0.0003 * *$ \\
\hline Community & $(0.0001)$ & (0.0001) & $(0.0001)$ & $(0.0002)$ & (0.0002) & $(0.0001)$ & $(0.0002)$ & $(0.0001)$ & (0.0001) \\
\hline Characteristics & $0.0017^{*}$ & $0.0007^{*}$ & -0.00002 & $0.0017 *$ & $0.0004 * *$ & 0.0001 & $0.0015^{*}$ & $0.0007^{*}$ & -0.0002 \\
\hline Dwelling & $(0.0001)$ & $(0.0001)$ & $(0.0001)$ & $(0.0002)$ & $(0.0002)$ & $(0.0002)$ & $(0.0002)$ & $(0.0001)$ & $(0.0002)$ \\
\hline Ownership & $\begin{array}{l}-0.0008^{*} \\
(0.0001)\end{array}$ & $\begin{array}{l}-0.0006^{*} \\
(0.0001)\end{array}$ & $\begin{array}{c}0.0002^{* * *} \\
(0.0001)\end{array}$ & $\begin{array}{c}-0.0007^{*} \\
(0.0002)\end{array}$ & $\begin{array}{l}-0.0005^{*} \\
(0.0002)\end{array}$ & $\begin{array}{c}0.0001 \\
(0.0001)\end{array}$ & $\begin{array}{l}-0.0006^{*} \\
(0.0001)\end{array}$ & $\begin{array}{c}-0.0006^{*} \\
(0.0001)\end{array}$ & $\begin{array}{c}0.0003^{* * *} \\
(0.0001)\end{array}$ \\
\hline Improved Drinking & 0.0035 & 0.0089 & 0.0024 & 0.0064 & $0.0464 *$ & -0.0069 & 0.0080 & $-0.0294^{*}$ & 0.0127 \\
\hline Water & $(0.0084)$ & $(0.0081)$ & (0.0076) & $(0.0123)$ & (0.0120) & $(0.0108)$ & $(0.0114)$ & (0.0105) & (0.0107) \\
\hline Improved & 0.0115 & $0.0126 * * *$ & -0.0034 & 0.0092 & $-0.0499 *$ & 0.0051 & 0.0073 & $0.0278 *$ & -0.0127 \\
\hline Sanitation & $(0.0079)$ & $(0.0076)$ & $(0.0072)$ & $(0.0114)$ & $(0.0112)$ & $(0.0102)$ & $(0.0108)$ & $(0.0100)$ & $(0.0101)$ \\
\hline $\begin{array}{l}\text { Source of } \\
\text { Electricity }\end{array}$ & & & & & & & & & \\
\hline Number of School & & & & & & & & & \\
\hline
\end{tabular}


INTERNATIONAL JOURNAL OF ACADEMIC RESEARCH IN BUSINESS AND SOCIAL SCIENCES

Vol. 9, No. 9, September, 2019, E-ISSN: 2222-6990 @ 2019 HRMARS

\begin{tabular}{|c|c|c|c|c|c|c|c|c|c|}
\hline \multicolumn{10}{|l|}{$\begin{array}{l}\text { Student-teacher } \\
\text { Ratios }\end{array}$} \\
\hline Iable-4: MIu & Lugit th & $2 \pi$ & (2)1 & . S III & ig crimar & $d$ by $\mathrm{Ge}$ & (- & ontin & \\
\hline \multirow{3}{*}{ Variables } & \multirow{2}{*}{\multicolumn{3}{|c|}{ All }} & \multicolumn{6}{|c|}{ Gender } \\
\hline & & & & \multicolumn{3}{|c|}{ Boys } & \multicolumn{3}{|c|}{ Girls } \\
\hline & $\begin{array}{l}\text { School and } \\
\text { Work }\end{array}$ & Work Only & Neither & $\begin{array}{c}\text { School and } \\
\text { Work }\end{array}$ & Work Only & Neither & $\begin{array}{c}\text { School and } \\
\text { Work }\end{array}$ & Work Only & Neither \\
\hline GRDP & $\begin{array}{l}-0.0009 * \\
(0.0001)\end{array}$ & $\begin{array}{l}-0.0003^{*} \\
(0.0001)\end{array}$ & $\begin{array}{l}-0.0003^{*} \\
(0.0001)\end{array}$ & $\begin{array}{l}-0.0009 * \\
(0.0001)\end{array}$ & $\begin{array}{l}0.00003 \\
(0.0001)\end{array}$ & $\begin{array}{l}-0.0004^{*} \\
(0.0001)\end{array}$ & $\begin{array}{l}-0.0009 * \\
(0.0001)\end{array}$ & $\begin{array}{l}-0.0007^{*} \\
(0.0001)\end{array}$ & $\begin{array}{l}-0.0001 \\
(0.0001)\end{array}$ \\
\hline Telephone & $\begin{array}{l}0.00004 \\
(0.0025)\end{array}$ & $\begin{array}{l}-0.0149 * \\
(0.0032)\end{array}$ & $\begin{array}{l}-0.0219 * \\
(0.0029)\end{array}$ & $\begin{array}{c}-0.0096^{* *} \\
(0.0043)\end{array}$ & $\begin{array}{l}-0.0412 * \\
(0.0060)\end{array}$ & $\begin{array}{l}-0.0217^{*} \\
(0.0043)\end{array}$ & $\begin{array}{c}0.0072 * * \\
(0.0030)\end{array}$ & $\begin{array}{l}-0.0009 \\
(0.0033)\end{array}$ & $\begin{array}{l}-0.0192 * \\
(0.0038)\end{array}$ \\
\hline $\begin{array}{l}\text { Computer } \\
\text { Island }\end{array}$ & $\begin{array}{l}0.0151^{*} \\
(0.0034)\end{array}$ & $\begin{array}{l}-0.0066 \\
(0.0051)\end{array}$ & $\begin{array}{l}-0.0167^{*} \\
(0.0046)\end{array}$ & $\begin{array}{c}0.0107^{* * *} \\
(0.0064)\end{array}$ & $\begin{array}{l}-0.0701^{*} \\
(0.0138)\end{array}$ & $\begin{array}{c}-0.0157^{* *} \\
(0.0074)\end{array}$ & $\begin{array}{l}0.0173 * \\
(0.0037)\end{array}$ & $\begin{array}{c}0.0061 \\
(0.0046)\end{array}$ & $\begin{array}{c}-0.0100 * * * \\
(0.0057)\end{array}$ \\
\hline$\overline{\text { Sumatera }}$ & $\begin{array}{l}-0.0213^{*} \\
(0.0044)\end{array}$ & $\begin{array}{l}-0.0039 \\
(0.0041)\end{array}$ & $\begin{array}{l}-0.0271 * \\
(0.0041)\end{array}$ & $\begin{array}{l}-0.0173^{*} \\
(0.0065)\end{array}$ & $\begin{array}{l}0.0245^{*} \\
(0.0065)\end{array}$ & $\begin{array}{c}-0.0147^{* *} \\
(0.0063)\end{array}$ & $\begin{array}{l}-0.0295^{*} \\
(0.0058)\end{array}$ & $\begin{array}{l}-0.0364 * \\
(0.0049)\end{array}$ & $\begin{array}{l}-0.0362 * \\
(0.0053)\end{array}$ \\
\hline Java & $\begin{array}{l}-0.0724^{*} \\
(0.0055)\end{array}$ & $\begin{array}{l}0.0060 \\
(0.0052)\end{array}$ & $\begin{array}{c}0.0064 \\
(0.0051)\end{array}$ & $\begin{array}{l}-0.0842^{*} \\
(0.0084)\end{array}$ & $\begin{array}{c}0.0111 \\
(0.0083)\end{array}$ & $\begin{array}{l}0.0212^{*} \\
(0.0076)\end{array}$ & $\begin{array}{l}-0.0670 * \\
(0.0071)\end{array}$ & $\begin{array}{l}-0.0065 \\
(0.0059)\end{array}$ & $\begin{array}{l}-0.0045 \\
(0.0067)\end{array}$ \\
\hline $\begin{array}{l}\text { Lesser Sunda } \\
\text { Islands }\end{array}$ & $\begin{array}{l}-0.0158 * \\
(0.0043)\end{array}$ & $\begin{array}{c}0.0045 \\
(0.0040)\end{array}$ & $\begin{array}{l}-0.0248 * \\
(0.0042)\end{array}$ & $\begin{array}{l}-0.0206^{*} \\
(0.0064)\end{array}$ & $\begin{array}{c}0.0154^{* *} \\
(0.0064)\end{array}$ & $\begin{array}{c}-0.0165 * * \\
(0.0065)\end{array}$ & $\begin{array}{c}-0.0121 * * \\
(0.0056)\end{array}$ & $\begin{array}{c}-0.0091^{* * *} \\
(0.0047)\end{array}$ & $\begin{array}{l}-0.0289 * \\
(0.0055)\end{array}$ \\
\hline & $-0.0170^{*}$ & $0.0170^{*}$ & $-0.0152 *$ & $-0.0210^{*}$ & $0.0329 *$ & -0.0007 & $-0.0173^{*}$ & -0.0014 & $-0.0265^{*}$ \\
\hline Kalimantan & $(0.0045)$ & $(0.0041)$ & $(0.0040)$ & $(0.0068)$ & $(0.0065)$ & $(0.0062)$ & (0.0058) & (0.0045) & $(0.0051)$ \\
\hline & -0.0008 & $0.0163^{*}$ & $-0.0125 *$ & 0.0097 & $0.0461^{*}$ & -0.0021 & $-0.0208^{*}$ & $-0.0211^{*}$ & $-0.0178^{*}$ \\
\hline Sulawesi & $(0.0042)$ & $(0.0040)$ & $(0.0040)$ & $(0.0064)$ & $(0.0064)$ & $(0.0062)$ & $(0.0055)$ & $(0.0046)$ & $(0.0051)$ \\
\hline & -0.0028 & $-0.0391 *$ & $-0.0450 *$ & -0.0024 & $-0.0276^{*}$ & $-0.0332 *$ & -0.0056 & $-0.0481^{*}$ & $-0.0547^{*}$ \\
\hline Maluku & $(0.0049)$ & $(0.0052)$ & $(0.0053)$ & $(0.0073)$ & $(0.0081)$ & $(0.0077)$ & $(0.0062)$ & $(0.0062)$ & (0.0075) \\
\hline $\begin{array}{l}\text { Chi Squared } \\
\text { Pseudo R-Squared }\end{array}$ & & $\begin{array}{c}41.39 \text { (d.f } 1 \\
0.2189 \\
155,237\end{array}$ & & & $\begin{array}{c}425.53 \text { (d.f } 1 \\
0.2299 \\
84,535\end{array}$ & & & $\begin{array}{c}417.27 \text { (d.f } 1 \\
0.2085 \\
70,792\end{array}$ & \\
\hline
\end{tabular}


INTERNATIONAL JOURNAL OF ACADEMIC RESEARCH IN BUSINESS AND SOCIAL SCIENCES

Vol. 9, No. 9, September, 2019, E-ISSN: 2222-6990 @ 2019 HRMARS

\begin{tabular}{|l|l|l|l|}
\hline $\begin{array}{l}\text { Number of } \\
\text { Observations }\end{array}$ & & & \\
\hline
\end{tabular}

Notes:

a. ${ }^{*}$ statistically significant at $1 \%$ level, ${ }^{* *}$ statistically significant at $5 \%$ level, ${ }^{* * *}$ statistically significant at $10 \%$ level.

b. Standard errors are reported in brackets. 
as opposed to the children of other relatives of the household head. For poor families, the above reasons might be one of the causes of this finding. For rich families, households with land are able to hire labor instead of their household members. In addition, since there is no compulsion for children to go to school in rich families and at the same time, the households did not face credit constraints, children are left at home, doing "neither work nor school". The gender coefficient shows a significant negative effect on the probability of "work only", the probability of "school and work" and the probability that a child will "neither work nor school".

Age of the head of the household significantly reduces the probability of "work only" and "work and school". Psacharopolous (1997) finds that the probability of working among children in Bolivia is higher among female-headed households than male-headed households (see also Mario, 2009). Ray (2000) also notes that femaleheaded households are more vulnerable to poverty and much more dependent on children's earnings. However, the coefficient of female headed households in the estimates shows insignificant effect, even though in gender boys-girls estimates.

Among household head and spouse characteristics, their education and the occupation have a significant impact on child activities. As noted by Bonsang and Faye (2005), highly educated parents have more information about the return from schooling therefore; they can help their children in their learning process efficiently which is resulting in lower dropout rate. Consistent with the previous empirical findings, a higher level of education among parents decreases the probability that a school-age child will "work only", "school and work" or do "neither" relative to the probability that the child will attend "school only". In other words, the parental education significantly reduces the probability that a school-age child will be in "work only" category, in "school and work" category and in" neither" category. Therefore, these findings confirm that household heads and spouses with higher level of human capital have better potential income than that of lower educated parents, which higher income parents decreases the chance of the children to be sent to "work only", "school and work" or "neither work nor school" rather than to "school only". The gender-divide estimates show that boys and girls are less likely to be involved in a working activity and "neither work nor school" as the head of the household and their spouse is more educated. In addition, there are noticeable gender differences between the estimates of this effect.

Some of the coefficients of household head's and spouse's occupation variables show significant results. For example, if household head's occupation is employer, then it is more likely for the child to specialise in "study and work" and "work only". In contrast, children are less likely to be in neither category. On the other hand, if the household head of a child is a casual worker, then it increases the probability that the child will "neither work nor school". In addition, the child is 0.1 percentage point less likely to "work only" relative to the reference category (household head's occupation is self-employed). The coefficient of spouse's occupation is found to be significant and positively associated with the probability of "work only". In particular, if the spouse of a household head is an employee, then it reduces the probability that the child will "neither work nor school" by 1.1 percentage points. 
Household income is predicted to have a positive impact on schooling, since in the presence of credit constraints; poorer households may have hard access to credit market to enable them to support both direct and opportunity costs of education (Guarcello et al, 2004). The variable that reflects the poverty status of the children's household, the total household income minus children income were included in the estimation. This variable (as suggested by Basu-Van Luxury Axiom) is predicted to have a positive impact on schooling, since in the presence of credit constraints, poorer households lack the resources in order to support both direct and opportunity costs of education (Bonsang and Faye, 2005). In addition, poorer households may send their children to work to earn extra income to make ends meet. Higher household income is significantly associated with a higher probability to "school and work" and a lower probability to "work only" and "neither work nor school" relative to the probability of "school only". However, these results may show a moderate income impacts. This is due to the fact that the inclusion of several variables which reflecting the quality of the living conditions of the household that may be positively correlated to household income. According to Bonsang and Faye (2005), this automatically weakens the household income impact on child activities. Moreover, a large part of working children live in an agricultural family in rural areas that it is difficult to evaluate the contribution of each child to household income, especially those children who help their parents. Consequently, endogeneity issue can downward bias impact of household income on the probability of working for children. Estimates show that, for boys and girls, the probability to work decreases significantly as household income increases, especially among boys compared to girls. The square of household income shows that the probability of "work only" and "neither work nor school" decreases with an increasing rate. However, the effect of household income (squared) on the probability of "school and work" is not significant.

Emerson and Souza (2008), in their study of child labor in Brazil, noted that the higher abilities commanded by earlier born children may enable them to command higher wages in the labor market than their later born siblings. In addition, in the case of families that cannot afford schooling for their earlier born children, they may send the later born children to school due to the income earned by their older siblings. The result confirms this finding where the probability of "school and work" increase as the child gets older and a similar result also shown on the probability of "work only". Moreover, the older the child, the more likely they will be in "neither work nor school" category by 0.4 percentage point. As a study by Grootaert (1998) in Cote d'Ivoire shows that the presence of siblings within a household influences children and whether they are likely to be in the labor market or in school (see also Patrinos and Psacharopolous, 1997 and Togunde and Richardson, 2006). In addition, as noted by Ray (2001, pg. 10), a child living in a household containing a large number of children is more likely to be living in poverty than a child residing in a household with a few children. The result indicates that an upsurge in the number of school-age children increases the probability of "work only", which is shown to be significant. In particular, an increase in the number of children with the age of 15-17 years is negatively related to the probability of "work only" and "neither work nor school". A naïve prediction which stated by Bonsang and Faye (2005), number of adults in the household would have a positive impact on the probability for children to attend school. This is due to 
the fact that more adults presence in the household are accountable to take care of young children and able to provide sufficient resources to the household. The estimates indicate that the number of adults significantly reduces the probability of "work only" and the probability of being "idle". These results suggest thus labor complementarities between adults and children. Furthermore, living in rural areas positively associated with the probability of "school and work", "work only" and "neither work nor school". The largest impact is among boys compared to girls. Particularly, the probability of boys' working is increased by $1.8 \%$ if they are living in rural areas, however, the result shows insignificant impact towards girls.

In Indonesia, computers still remain a luxury in many schools and households. Only about $21 \%$ of junior high schools and $37 \%$ of high schools had computer facilities in $2010^{4}$. As in Bezile, Young (2002) notes that students in urban schools have to pay higher fees than those in rural areas since urban schools provide more services such as typing, computer and security. In addition, the public ICT literacy in Indonesia is still very low including students and teachers, especially those who live in the perimeters or remote areas (Yuhetty, 2002). Therefore, having a computer in a household shows a high financial ability to send children to school and the child is less likely to work. The estimate shows that having computer in the household significantly reduces the probability of "neither work nor school" by 1.7 percentage point relative to the probability of "school only". In contrast, having a computer in the household is significantly related to the higher probability of "work and school".

As findings by Maitra and Ray (2002) indicate, the improvements of the facilities inspire working and 'idle' children to combine work and school in Pakistan. The children's time allocation depends on the access to basic services such as water and electricity (Bonsang and Faye, 2005). Having these services in the household reduces the opportunity cost of schooling as children are free from the responsibility to fetching water and collecting wood for cooking or lighting. These facilities help in reducing child labor and increasing school attendance. Based on the study by Guarcello et al (2004), their finding shows households that have access to water and electricity are more likely to send their children to school. Maitra and Ray (2002) found that the provision of improved electricity facility in Peru encourages schooling and the provision of improved water supply facility encourages children to combine schooling and working. SUSENAS does not contain information of basic services directly; however, it is possible to construct a proxy variable that reflects the degree of development of the infrastructure in the household in each of province. Guarcello et al. (2004) found that having access to water increases the number of children attending school and decreases the number of children in working or in neither work nor school category. Based on a study by Bonsang and Faye (2005) in Senegal, they construct a variable that indicates the proportion of households having those basic services by district of census. Thus, these variables were included in the stimation to investigate the impact of the development of the infrastructures in the areas where household live. Having an access to water and improved sanitation significantly

${ }^{4}$ Computers for Schools: Why Invest in Computers for Schools. Retrieved February 10, 2014 from http://www.indonesiandiasporafoundation.org/read-why-invest-incomputers-for-schools.html 
increases the probability of "school and work" relative to the "school only", however the effect were small. The child is less likely to "work only" if the household having an electric. In addition, having a direct access to water has a negative impact on the probability of "neither work nor school". Results also indicate that the presence electric lighting significantly increases the probability of "neither work nor school". This result is similar to what was found in Ghana by study of Guarcello et al (2004).

A high student-teacher ratio negatively impacts the probability of "work only" relative to the "school only". The result indicates that an increase in the studentteacher ratio shows underfunded schools, which need more funding for education. This makes the children more likely to drop out of school and be in the 'work only' category. The increase in gross regional domestic product (GRDP) showed similar effects to household income, which significantly decreases the probability of "school and work", "work only" and "neither work nor school" as opposed to "school only". Having a basic services and infrastructures and improvement of the availability of schools, teachers, and regional economic status highly affect boys relative to girls.

\section{Conclusion}

A result of this study is worth emphasizing that an increase in household income and GRDP, increase in the owning a dwelling and having a direct access to water reduces the child's probability to be in neither work nor school category. It is interesting to look at the effects of access to basic services by age. The effects of basic services are higher for relatively young children and relatively old children. This seems to specify that availability of water; sanitation and electricity help to increase school and work at younger ages and may reduce dropout rate at later ages. The negative effect of these basic services has on the participation of children in working tends to be higher for relatively older children. In addition, "idle" children seem to particularly benefit from having access to basic services at a young and later age. The increase in schooling seems consequently to be due to children being withdrawn from work or from being in neither work nor school category. On the other hand, access to basic services appears to help reduce the possibility to drop out from school and join the labor market.

Furthermore, children living in households that is headed by female are more likely to devote most of their time to work and being "idle' especially for girls, which reflects that working girls are substitute of adult female. The result reveals that household head and spouse background has a significant impact on children's status. Children in a household where the head and the head's spouse has a relatively high level of education are less likely to work and more likely to attend school. The estimates show that better educated household head and the spouse reduces the probability of children to combine work and schooling and be in neither work nor school category. This impact is likely to support the argument of the importance of adult education on children outcomes. Therefore, educating the adults in the household could be useful in improving children outcomes. The results represent the factors influencing the incidence of child labor along with other activities, thus limiting the study only on the supply side of the determinants of child's activity. However, this study does not cover the demand side of child's activity in Indonesia. In addition, the estimation also did not cover all the possibilities that might influence the household's 
decision on child's activity such as migration, trade, weather, and capital market. Therefore, further analysis is required to examine these effects.

However, these findings have important implications for current and future efforts to reduce the probability of working and increase their participation in school. Since there is evidence that working is common among older children, older children who cannot continue with secondary school should be targeted by policy makers. In addition, older girls who are dropped out from schooling due to early marriage should be considered, as well. For children of less educated and poor parents, they need more attention as they cannot afford schooling compared to other families. However, the main initiatives that have to be focused are to improve the welfare of the rural communities. For example, access to basic services can influence and modify the decision of the household regarding children activities through "price" and income effect. In particular, according to Bonsang and Faye (2005), easier access to the basic services including water, sanitation and electricity might reduce the value of children's time in supplement the household income as opposed to investment in human capital accumulation. Moreover, the value of children's time might be affected indirectly by access to basic services, which might produce a positive income effect that reduces the value of children's time in contributing to current income. Therefore, providing these basic services should be the priority in reducing child labor, especially in rural areas.

Moreover, policy makers should target the availability of teachers where school enrolment is low. Appropriate policies are needed, such as subsidy programs for those children who are combining school and work, since they are more likely to end up only working or be 'idle' children. Therefore, policies ought to shift children who are combining school and work toward full-time schooling. Hence, the availability of good schools, reinforced adult educational levels, and appropriate subsidy programs will help curb the prevalence of child labor and improve the probability that children stay in school. Thus, government agencies together with communities, nongovernment organizations and international organizations have to work together to overcome the problem.

\section{Acknowledgement}

This research was supported by Universiti Malaysia Sarawak under Special Short Term Grant (F01/SpSTG/1572/2017).

\section{References}

Akabayashi, H., and Psacharapoulos, G. (1999). The Trade-off Between Child Labor and Human Capital Formation: A Tanzanian Case Study. The Journal of Development Studies, 35(5): 120-140.

Beegle, K., Dehejia, R. H., Gatti, R., and Krutikova, S. (2008). The Consequences of Child Labor: Evidence from Longitudinal Data in Rural Tanzania. The World Bank Policy Research Working Paper Series, (No. 4677).

Bonsang, E. and Faye, O. (2005). Working or Schooling: What Determine Children's Time Allocation in Senegal. CREPP Working Papers (No. 0508). 
Burki, A. A., and Fasih, T. (1998). Households' Non-Leisure Time Allocation for Children and Determinants of Child Labor in Punjab, Pakistan. The Pakistan Development Review, 37(4): 899-914.

Cartwright, K., and Patrinos, H. A. (1999). Child Labor in Urban Bolivia. In The Policy Analysis of. Child Labor: A comparative Study. Edited by Christian Grootaert and Harry Anthony Patrinos, Washington, D.C.: World Bank

Cigno, A., and Rosati, F. C. (2002). Child Labor, Education and Nutrition in Rural India. Pacific Economic Review, 7: 1-19.

Deb, P., and Rosati, F. (2001). Determinants of Child Labor and School Attendance: The Role of Household Unobservable. Economics Working Paper Archive at Hunter College 02/9, Hunter College Department of Economics.

Duryea, S., and Arends-Kuenning, M. (2003). School Attendance, Child Labor and Local Labor Market Fluctuations in Urban Brazil. World Development, 31(7): 1165- 1178.

Edmonds, E. V. (2003). Should We Boycott Child Labor?. Ethique Economique/Ethics and Economics, vol. 1.

Emerson, P. M. and Souza, A. P. (2008). Birth Order, Child Labor and School Attendance in Brazil. World Development, 36(9): 1647-1664.

Grootaert, C. (1998). Child Labor in Cote d'Ivoire: Incidence and Determinants. The World Bank Working Paper (No. 1905).

Grootaert, C., and Patrinos, H.(2002). A Four-Country Comparative Study of Child Labor. The World Bank.

Guarcello, L., Lyon, S., and Rosati, F. C. (2004). Child Labor and Access to Basic Services: Evidence from Five Countries. Understanding Children's Work (UCW) Project Working Paper.

Heady, C. (2003). The Effect of Child Labor on Learning Achievement. World Development, 31(2): 385-398.

Islam, M., Islam., Ali, M. A., and Rahman, M. (2009). School Attendance of Child Labor: A Pilot Survey in Gaibandha District of Bangladesh. International NGO Journal, 4(4): 109-115.

Jeong, J. (2005). The Determinants of Child Labor and Schooling in Honduras, Nicaragua, and Panama. Retrieved January 25, 2012 from http://economics.stanford.edu/files/Theses/Theses_2005/Jeong.pdf

Kambhampati, U. S., and Rajan, R. (2008). The 'Nowhere' Children: Patriarchy and the Role of Girls in India's Rural Economy. Journal of Development Studies, 44(9): 1309- 1341.

Khanam, R. (2004). Impact of Child Labor on School Attendance and School Attainment: Evidence from Bangladesh. Munich Personal RePEc Archive (MPRA) Working Paper (No. 9397).

Khanam, R. (2005). Child Labor in Bangladesh: Trends, Patterns and Policy Options. Munich Personal RePEc Archive (MPRA) Working Paper (No. 8008).

Khanam, R., and Rahman, M. M. (2005). Child Work and Schooling in Bangladesh: The Role of Birth Order. Munich Personal RePEc Archive (MPRA) Working Paper (No. 8009). 
Khanam, R., and Ross, R. (2005). Impact of Child Labor on School Attendance and School Attainment: Evidence from Bangladesh. Munich Personal RePEc Archive (MPRA) Working Paper (No. 9397).

Levison, D., Moe, K. S., and Knaul, F.M. (2001). Youth Education and Work in Mexico. World Development, 29(1): 167-188.

Maddala, G. (1983). Limited Dependent and Qualitative Variables in Econometrics. Cambridge: Cambridge University Press.

Maitra, P., and Ray, R. (2002). The Joint Estimation of Child Participation in Schooling and Employment: Comparative Evidence from Three Continents. Oxford Development Studies, 30(1): 41-62.

Mario, V. (2009). School Attendance, Child Labor and Gender Bias in Morocco. DISES Working Paper (No. 0854).

McFadden, D. (1973). Conditional Logit Analysis of Qualitative Choice Behaviour in Paul Zarembka (ed.) Frontiers in Econometrics'. New York: Academic Press.

Moyi, P. (2011). Child Labor and School Attendance in Kenya. Educational Research and Reviews, 6(1): 26-35.

Patrinos, H. A., and Psacharopoulos, G. (1995). Educational Performance and Child Labor in Paraguay. International Journal of Educational Development, 15(1): 4760.

Patrinos, H. and Psacharapoulos, G. (1997). Family Size, Schooling, and Child Labor in Peru: An Empirical Analysis. Journal of Population Economics, 10(4): 387-405.

Psacharopoulos, G. (1997). Child Labor versus Educational Attainment: Some Evidence from Latin America. Journal of Population Economics, 10: 377-386.

Ranjan, P. (2004). Why Children Work, Attend School, or Stay Idle: Theory and Evidence. Econometric Society 2004 Australasian Meetings 362, Econometric Society.

Ray, R. (2000). Analysis of Child Labor in Peru and Pakistan: A Comparative Study. Journal of Population Economics, 13(1): 3-19.

Ray, R. (2001). Child Labor and Child Schooling in South Asia: A Cross Country Study of their Determinants. ASARC Working Papers (No. 2001-09), The Australian National University, Australia South Asia Research Centre.

Ray, R. and Lancaster, F. (2003). Does Child Labor Affect School Attendance and School Performance? Multi Country Evidence on SIMPOC Data. Discussion Paper 2003-2004 School of Economics, Australia: University of Tasmania.

Rickey, L. (2009). The Determinants of Child Labor and Schooling in the Philippines. Department of Economics, Stanford University.

Ridao-Cano, C. (2001). Evaluating the Impact of Working While in School on School Progress: The Case of Rural Bangladesh. Population Aging Center, University of Colorado (Working Paper PAC 2001-0002).

Rosati, F. C., and Rossi, M. (2002). Children's Working Hours, School Enrollment and Human Capital Accumulation: Evidence from Pakistan and Nicaragua. World Bank Economic Review, 17(2).

Togunde, D., and Richardson, S. (2006). Household Size and Composition as Correlates of Child Labor in Urban Nigeria. Africa Development, 31(1): 50-65.

Triningsih, N., and Ichihashi, M. (2010). The Impact of Poverty and Educational Policy on Child Labor in Indonesia. IDEC Hiroshima University Discussion Paper. 
Wales, T. J. and A. D. Woodland (1977) Estimation of the Allocation of Time for Work, Leisure, and Housework, Econometrica, 45(1):115-132.

Young, R. A. (2002). Child Labor in Belize: A Qualitative Study. The paper prepared for The Statistical Information and Monitoring Programme on Child Labor (SIMPOC), International Labor Organization (ILO).

Yuhetty, H. (2002). ICT and Education in Indonesia. Retrieved September 19, 2012 from

http://unpan1.un.org/intradoc/groups/public/documents/apcity/unpan0112 86.pdf 